\title{
Unravelling climate change impacts from other anthropogenic influences in a subalpine lake: a multi-proxy sediment study from Oberer Soiernsee (Northern Alps, Germany)
}

\author{
Andrea M. Hofmann • Wolfgang Kuefner · Christoph Mayr • Nathalie Dubois • \\ Juergen Geist • Uta Raeder
}

Received: 8 September 2020/Revised: 29 May 2021/Accepted: 10 June 2021/Published online: 28 June 2021

(C) The Author(s) 2021

\begin{abstract}
Mountain lakes are increasingly impacted by a series of both local and global disturbances. The present study reveals the eutrophication history of a remote subalpine lake (Oberer Soiernsee, Northern Alps, Germany), triggered by deforestation, alpine pasturing, hut construction, tourism and atmospheric deposition, and identifies the intertwined consequences of on-going global warming on the lake's ecosystem. The primary objective was to disentangle the various direct and indirect impacts of these
\end{abstract}

Handling editor: Jasmine Saros

Supplementary Information The online version of this article (doi:https://doi.org/10.1007/s10750-021-04640-8) contains supplementary material, which is available to authorized users.

A. M. Hofmann $(\bowtie) \cdot$ W. Kuefner · J. Geist · U. Raeder Aquatic Systems Biology Unit, Limnological Station Iffeldorf, Technical University of Munich, Hofmark 1-3, 82393 Iffeldorf, Germany

e-mail: a.hofmann@tum.de

C. Mayr

Institute of Geography, Friedrich-Alexander-University Erlangen-Nürnberg, Wetterkreuz 15, 91058 Erlangen,

Germany

C. Mayr

Palaeontology and Geobiology, and GeoBio Center, Ludwig-Maximilian University, Richard-Wagner-Str. 10, 80333 Munich, Germany multiple stressors via down-core analyses. Our multi-proxy approach included subfossil diatom assemblages, carbon and nitrogen stable isotope ratios and subfossil pigments from dated sediments. Shifts within the diatom assemblages were related to variations in trophic state, lake transparency, water temperature and thermal stratification. The organic carbon isotope $\left(\delta^{13} \mathrm{C}_{\text {org }}\right)$ records, the diatom valve density and the pigment concentrations documented the development of primary production and composition. Total nitrogen isotope values $\left(\delta^{15} \mathrm{~N}\right)$ are more likely to reflect the history of atmospheric nitrogen pollution than lake-internal processes, also mirrored by the decoupling of $\delta^{15} \mathrm{~N}$ and $\delta^{13} \mathrm{C}_{\text {org }}$ trends. The composition of sedimentary pigments allowed a differentiation between planktonic and benthic

N. Dubois

Surface Waters - Research + Management, Eawag,

Überlandstrasse 133, 8600 Dübendorf, Switzerland

N. Dubois

Department of Earth Sciences, ETH Zürich, Sonnegstrasse 5, 8092 Zurich, Switzerland 
primary production. Concordant trends of all indicators suggested that the lake ecosystem passed a climatic threshold promoted by local and longdistance atmospheric nutrient loadings.

Keywords Warming - Eutrophication - Atmospheric nitrogen deposition - Diatoms - Stable isotopes ·

Pigments

\section{Introduction}

Mountain regions are particularly sensitive to climate change. They are hotspots of biodiversity (Körner et al., 2016) and very valuable drinking water reservoirs (Beniston, 2006). The recent warming observed in the European Alps since the mid-1980s is roughly three times higher than the global average (Bogataj, 2007) and climate models predict even more severe changes in coming decades (IPCC, 2013; Stocker, 2020). Coupled with the intense warming, significant changes in the Alpine hydrological cycle were projected, with a tendency to more intense winter precipitation (increasingly as rain) and significantly reduced summer rainfall (Warscher et al., 2019). An upward shift of the snow line and heavy rainfall events notably increase the frequency and the magnitude of flash floods, landslides and debris flows (Bätzing, 2015).

Recent global warming is affecting mountain lake ecosystems by a series of direct and indirect effects, altering the dynamics of these extremely sensitive habitats. External drivers such as climate-induced changes of catchment soil and vegetation cover may affect the chemical characteristics of the lakes (Fritz, 2008; Rosbakh et al., 2014). For instance, extreme precipitation events alternating with periods of drought will increase soil erosion and consequently nutrient input from the catchments into the lakes (Jeppesen et al., 2010). Warming thus has a direct effect on the lake ecosystem function and biodiversity by stimulating biological processes, resulting in higher internal phosphorus loadings, extension of the growing season (Magnuson et al., 2000; O'Reilly et al., 2015), and alteration of lake stratification patterns (Smol et al., 2005; Winder \& Sommer, 2012). More stable and longer stratifications trigger compositional shifts within the phytoplankton communities to the benefit of mobile, small-sized or colony-forming species (Winder et al., 2009; Michelutti et al., 2015). Additionally, changes in precipitation patterns affect the water balance of lakes, especially in karstified catchment areas, leading to significant changes in water levels or enhanced seasonal water level fluctuations (Lauber \& Goldscheider, 2014). All these complex impacts of climate change have been superimposed during the Anthropocene by simultaneous fertilisation via a diffuse deposition of atmospheric nitrogen and by local anthropogenic disturbances, e.g. mountain huts, forestry or alpine pastures (McMaster \& Schindler, 2005; Jeppesen et al., 2010).

Numerous proxies that are archived in lake sediments are valuable to track such impacts (Smol, 2010), thus allowing the study of various responses of the aquatic ecosystem to these environmental stressors. However, sedimentary records are often difficult to understand. Numerous drivers may trigger changes in sedimentary records by affecting the lake ecosystem in a series of direct and indirect ways. Lake sediments integrate sedimentary organic matter from both allochthonous and autochthonous sources and a number of internal lake processes complicate the interpretation of past climate or nutrient situations from sedimentary archives (Batterbee et al., 2012; Catalan et al., 2013; Rogora et al., 2018). Unravelling the combined effects of climate warming and eutrophication in down-core studies is indeed a great challenge, because the symptoms may be rather similar and both impacts have appeared synchronously (Jeppesen et al., 2010). Due to the complex interactions between biotic and abiotic components and between internal and external driving factors the analyses of several proxies should be carried out (Birks \& Birks, 2006). Different proxies mirror different environmental factors and also have different strengths and weaknesses. By combining multiple proxies, their strengths can be exploited and their weaknesses identified (Mann, 2002b).

For interpreting the long-term changes in lake ecosystem structure of the small subalpine Oberer Soiernsee, a multi-proxy paleolimnological study was carried out based on sedimentological (event layers), biological (diatoms), biochemical (pigments) and geochemical (stable isotopes) paleoindicators, supported by data from a 3 years sampling campaign (2014-2016; Hofmann et al., 2020). Additionally, historical information recorded in Alpine Club 
yearbooks and interviews with landowners and forest office were used to better interpret the results.

Diatoms are the most widely used bioindicators in paleolimnological studies inferring past environmental conditions (Stoermer \& Smol, 2010). They are generally highly abundant and taxonomically diverse in any freshwater systems and, due to their siliceous cell walls, diatom valves are usually well preserved in the lake sediments (Smol \& Cumming, 2000). Furthermore, many diatom taxa have well-defined optima and tolerances regarding water temperatures and nutrient concentrations or preferences for a given habitat. They response sensitively and due to their fast reproduction and migration rates also rapidly to a wide range of environmental changes of their aquatic environment (Smol, 2008). Climate-related changes of lake properties, such as length of the growing season, water column mixing processes and light availability, directly and indirectly alter diatom community composition, dynamics and size structure of both periphytic and planktonic diatom assemblages (e.g. Weckström et al., 1997; Rühland et al., 2015; Boeff et al., 2016; Griffiths et al., 2017). Especially the recent success of small-celled centric species related to increased thermal stability and associated changes in light and nutrient availability has been observed in alpine paleolimnological records around the world (Lotter \& Bigler, 2000; Rühland et al., 2008; Catalan et al., 2013; Michelutti et al., 2015). Nutrient enrichment mediated by disturbances within the catchment area also may result in the reorganisation of diatom communities. Therefore, quantitative diatom-based inference models can be used to reconstruct past trophic states of lakes (Lotter et al., 1998; Stoermer \& Smol, 2010).

Sedimentary pigments are particularly valuable in multi-proxy studies. They are often the only fossil remains of non-siliceous algae and therefore provide a more complete picture of phototrophic communities (Lami et al, 2000). Records of paleopigments can be used to reconstruct taxonomic composition and biomass of past phytoplankton and periphyton communities (Leavitt \& Hodgson, 2001). As nutrient supply and the lake's thermal dynamics are important drivers that regulate algal composition and production (Reynolds, 2006), analyses of sedimentary pigments can be used to detect climate changes and past trophic conditions (Tõnno et al., 2019). However, in comparison to diatoms, pigments are labile compounds. Their degradation via chemical oxidation, photo-oxidation and herbivore grazing begins immediately after the death of the organism (Leavitt, 1993) and the decomposition continues after deposition in the surface sediments (Sanger, 1988). The rate of degradation depends on sinking rate, water temperature, $\mathrm{pH}$, the availability of light and oxygen, the grazing pressure, turbulences and bioturbation. Additionally, the degree of chemical stability and preservation varies between the individual pigments (Leavitt \& Hodgson, 2001). Therefore, the pigments are deposited on surface sediments in various stages of decay, depending on the type of pigment and the degree photo- and chemical oxidation and biologically mediated destruction (Leavitt, 1993), which considerably complicates the interpretation of paleopigment analyses. In shallow or highly transparent oligotrophic lakes the development of an active autotrophic biofilm on the surface sediment is another important source of sedimentary pigments. Hence, the paleopigment composition in the surface sediments is dominated by the periphytic in situ production and the phytoplankton marker pigments are underrepresented (Buchaca \& Catalan, 2008). Therefore, changes between planktic and benthic sources of the sedimentary pigments provide valuable information about changes in the extension of the euphotic zone.

The nitrogen $\left(\delta^{15} \mathrm{~N}\right)$ and carbon $\left(\delta^{13} \mathrm{C}_{\text {org }}\right)$ isotope fingerprints as well as the TOC/TN (total organic carbon/total nitrogen) ratios of bulk sediment provide valuable information on the origin of sedimentary organic matter $(\mathrm{OM})$ and help to distinguish between autochthonous or allochthonous sources (Meyers \& Teranes, 2001). In cases where the sedimentary OM was predominantly autochthonous, testified by low TOC/TN ratios, the records of $\delta^{13} \mathrm{C}_{\text {org }}$ and $\delta^{15} \mathrm{~N}$ were used to reconstruct past trophic conditions and changes in nutrient availability (Braig et al., 2013). The isotopic composition of the dissolved inorganic carbon (DIC) pool is controlled by the signature of atmospheric $\mathrm{CO}_{2}$ permanently diffusing into the lake and by photosynthesis/respiration rates (Wetzel, 2001; Braig et al., 2013). $\delta^{13} \mathrm{C}_{\text {org }}$ concentrations increase with enhanced photosynthetic productivity (McKenzie, 1985). Algae preferentially assimilate ${ }^{12} \mathrm{CO}_{2}$, while the heavier isotopologue containing ${ }^{13} \mathrm{C}$ gradually accumulates in the pool of dissolved inorganic carbon (Farquhar et al., 1989). Thus, primary producers will take up more and more accumulated ${ }^{13} \mathrm{CO}_{2}$ 
with an increasing assimilation. This fact is reflected by the increasing accumulation of ${ }^{13} \mathrm{C}$ in the biomass and finally in the sediments after the algae died and sunk. However, $\delta^{13} \mathrm{C}_{\text {org }}$ values may initially decline during the first phase of eutrophication, when anaerobic microbial degradation dominates, which releases partly oxidised, ${ }^{12} \mathrm{C}$-enriched methane into the water column (Hollander \& Smith, 2001).

The interpretation of nitrogen isotope signals is complicated due to the biogeochemical complexity of the nitrogen cycle in lakes (Meyers \& Teranes, 2001). Nitrogen is available to primary producers in various forms (ammonia, hydroxylamine, nitrate, nitrite), and the multitude of fractionation effects, transformation pathways and biochemical in-lake processes permanently alter the dissolved inorganic nitrogen (DIN) pool of a lake (Wetzel, 2001). Photosynthesis progressively enriches the DIN reservoir with ${ }^{15} \mathrm{~N}$ as algae preferentially incorporate ${ }^{14} \mathrm{~N}$ (Fogel \& Cifuentes, 1993). Shifts in phytoplankton taxa composition are also known to trigger $\delta^{15} \mathrm{~N}$ variations in sedimentary OM due to the various ways in which DIN is used and fractionating effects among diverse algae groups (DeNiro \& Epstein, 1981; Lehmann et al., 2004; $\mathrm{Gu}, 2009)$. Sedimentary $\delta^{15} \mathrm{~N}$ variations also provide information about past hypolimnetic oxygen concentrations, as increased denitrification rates caused by anoxic bottom water lead to ${ }^{15} \mathrm{~N}$ enriched OM (Teranes \& Bernasconi, 2000; Finlay \& Kendall, 2007; Braig et al., 2013). Additionally, external nitrate loadings may increase (human and animal waste) or decrease (deposition of atmospheric nitrogen) $\delta^{15} \mathrm{~N}$ values (Kendall, 1998; Hastings et al., 2009).

The aim of our study was to reconstruct the environmental history of the remote Oberer Soiernsee since the outgoing Little Ice Age (AD 1840-1970), unravelling the multiple influences on the lake and their complex effects on its ecosystem. We hypothesised that (1) a series of human impacts (deforestation, alpine pasture, eutrophication, $\mathrm{N}$ fertilisation, climate warming) are recorded in the lake sediments and (2) our multi-proxy approach will allow us to disentangle these various impacts. We expected that (3) shifts within the diatom flora in particular would reflect the effects of global warming.

\section{Study site}

Lake Oberer Soiernsee $\left(47^{\circ} 29^{\prime} 32^{\prime \prime} \mathrm{N}, 11^{\circ} 20^{\prime} 44^{\prime \prime} \mathrm{E}\right)$ is located $\sim 75 \mathrm{~km}$ south of Munich (Bavaria, Germany) in the Northern Calcareous Alps near the present treeline ecotone (1,558 $\mathrm{m}$ a.s.l.) (Fig. 1). The lake is of glacial origin (März, 1903) and the catchment geology is dominated by Triassic limestone and dolomite, locally covered by moraine and postglacial deposits (Schmidt-Thomé, 1953). Due to karstification, underground drainage dominates, while surface runoff has been observed only during heavy rainfall events (Hofmann et al., 2020). The lake has no permanent surface inflow and drains exclusively through the permeable end moraine deposits into the adjacent lake Unterer Soiernsee (1,553 $\mathrm{m}$ a.s.1.). Catchment vegetation ranges from subalpine grassland with patches of Pinus mugo Turra ssp. mugo and Picea abies L. Karst to treeless alpine meadows with shrubs (e.g. Rhododendron hirsutum L., Carex sempervirens Vill.) on poorly developed soils and fellfields. Aquatic vegetation is characterised by mixed stands of Chara contraria A. Braun ex Kützing and Chara tomentosa L. and scattered populations of Potamogeton alpinus Balb. The elongated lake has a surface area of 3.46 ha and a maximum water depth of $14.5 \mathrm{~m}$ (Fig. 1). Lake Oberer Soiernsee is an oligo- to mesotrophic $\left(\right.$ mean $\mathrm{TP}=13 \mu \mathrm{g} \mathrm{l^{-1 }}$ ), dimictic lake with mean $\mathrm{NO}_{3}{ }^{-}-\mathrm{N}$ values of $330 \mu \mathrm{g}^{-1}$ and mean $\mathrm{NH}_{4}{ }^{+}-\mathrm{N}$ values of $20 \mu \mathrm{g}^{-1}$. The average lower limit of the euphotic zone is around $10 \mathrm{~m}$, resulting in aphotic conditions at the deepest area of the basin (Hofmann et al., 2020). Seasonal lake-level fluctuations $(1.8 \mathrm{~m})$ were observed with a maximum water level after snowmelt and a minimum in autumn. The carstified, calcareous catchment causes a low conductivity $\left(192 \mu \mathrm{S} \mathrm{cm}^{-1}\right)$ and a high $\mathrm{pH}$ (8.7). Phytoplankton biomass was consistently below $2 \mathrm{~g} \mathrm{~m}^{-3}$ throughout two successive growing periods. Detailed information regarding the lake's physical and chemical characteristics as well as phytoplankton analyses have already been published (Hofmann et al., 2020). The alpine meadows surrounding the lake were traditionally used for summer cattle grazing. A hut of the German Alpine Club (1,616 m a.s.l.) and a small private mountain cabin (1,560 $\mathrm{m}$ a.s.1.), both highly frequented during summer months, are situated within the lake catchment. The huts were built in AD 1866 on King Ludwig II's order. Since AD 1887, they have been 


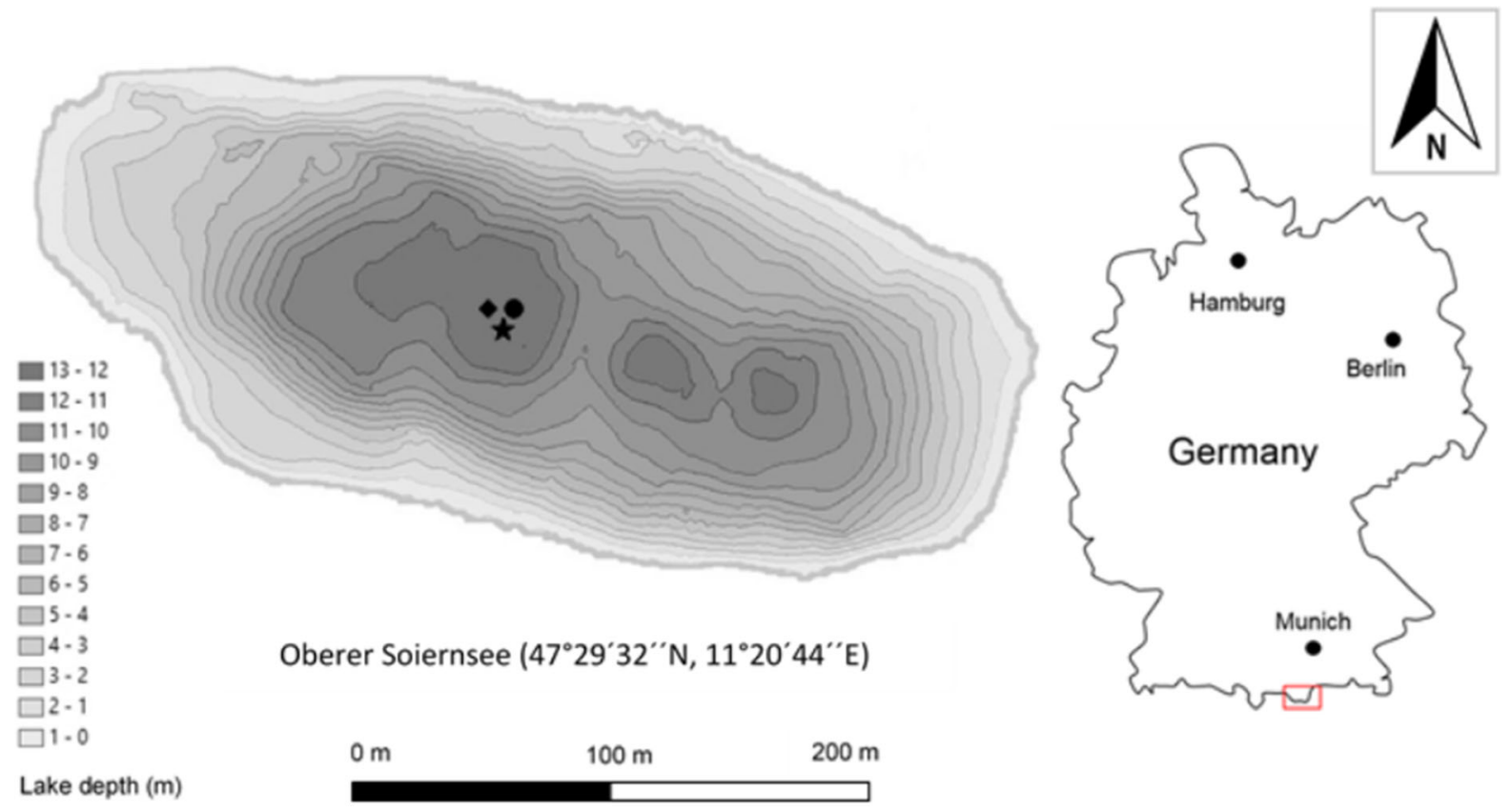

Fig. 1 Geographical position of Oberer Soiernsee in southern Germany (right) and bathymetric map of the lake (left). Coring location of C1 (circle), C2 (star), and C3 (rhomb)

put to increasing use, first as hunting lodges and later as Alpine Association cottages (Müller, 1922). In the small cabin situated directly at the lake, the number of overnight stays remained below 100 per year before $\mathrm{AD}$ 1960 and has risen sharply since then to 250-450 per year (Yearbooks of the Alpine Club Section Hochland 1920-2016). A dry toilet close to the northern shore in particular may be responsible for diffuse nutrient loadings, as indicated by higher trophic levels calculated at the northern littoral zone (Hofmann et al., 2020).

\section{Materials and methods}

Sediment coring

A gravity corer (Uwitec, Mondsee, Austria) equipped with 6-cm-diameter core tubes was used to obtain three sediment cores from the deepest area of the lake basin, located by echo sounding (HDS8, Lowrance, Tulsa, USA). The master core ( $\mathrm{C} 1$; length $29 \mathrm{~cm})$ was sampled in June 2015 to carry out stable isotope analyses and core chronology. C2 (length $23 \mathrm{~cm}$ ) was taken in June 2017 for geochemical, diatom and pigment analyses. The sediment cores were transported cooled and light-protected and split into two halves in the laboratory. The first halves of the cores were sliced at continuous $1 \mathrm{~cm}$ intervals under subdued green light. For pigment analyses, subsamples were stored in the dark at $-24^{\circ} \mathrm{C}$ until freezedrying. The other halves of the cores were first described lithologically. They were then subsampled at $1 \mathrm{~cm}$ intervals too and freeze-dried in plastic vials for diatom analysis, dating and stable isotope analysis (Christ 1-4 Loc; $48 \mathrm{~h},-47^{\circ} \mathrm{C}$ ). In October 2018, a third core $(\mathrm{C} 3)$ was obtained to measure the $\mathrm{pH}$ values of the sediment-water interface and the sediment pore water at different sediment depths.

Core chronology

The age model is based primarily on ${ }^{210} \mathrm{~Pb}$ dating, supported by peak signals of ${ }^{137} \mathrm{Cs}$. Freeze-dried and fine-ground sediment subsamples were analysed by gamma spectrometry (High-purity Germanium Well Detector, HPGe, Canberra, USA) at Eawag (Dübendorf, Switzerland). Accumulation rates were determined using both ${ }^{210} \mathrm{~Pb}$ and ${ }^{137} \mathrm{Cs}$ radionuclides. ${ }^{210} \mathrm{~Pb}$ chronologies were calculated from unsupported isotopes using the CRS model (Constant Rate of Supply, Appleby, 2001). The anthropogenic ${ }^{137} \mathrm{C}$ was used to 
confirm the ${ }^{210} \mathrm{~Pb}$ dates. ${ }^{137} \mathrm{Cs}$ is a stable and clear time marker as it first appeared in 1951-1954 and peaked in 1963 as a result of atmospheric nuclear weapon testing fallout (Appleby, 2001). A second peak of ${ }^{137} \mathrm{Cs}$ activity is related to the Chernobyl nuclear accident in 1986 (Kirchner, 2011). The first recovered core (C1) was dated. The chronology was transferred to $\mathrm{C} 2$ via lithological (event layers) and $\delta^{13} \mathrm{C}_{\text {org }}$ correlation (Mayr et al., 2005; Berthon et al., 2014).

\section{Diatom analyses}

For diatom preparation, $1.6 \mathrm{ml}$ of freeze-dried sediment of the $\mathrm{C} 2$ subsamples were treated using the hot $\mathrm{H}_{2} \mathrm{O}_{2} / \mathrm{K}_{2} \mathrm{Cr}_{2} \mathrm{O}_{7}$ method (DIN EN 13946:2014-07). The cleaned diatom material was filled into glass vials and was adjusted with distilled $\mathrm{H}_{2} \mathrm{O}_{2}$ to a fixed volume $(5 \mathrm{ml})$. Permanent slides were prepared by first dropping $50 \mu \mathrm{l}$ of several dilutions (1:10, 1:30, 1:50) of the cleaned diatom material on cover glasses $(\varnothing$ $12 \mathrm{~mm}$ ) and then embedding the dried material in Naphrax (Refractive Index $=1.7$ ). At least 550 diatom valves per sample were identified under oil immersion at $\times 1,000$ magnification using a light microscope (Aristoplan and Labovert, Leitz, Wetzlar, Germany). Diatom taxonomy followed Krammer \& Lange-Bertalot (1986-1991), Lange-Bertalot (1993), LangeBertalot et al. (1996), Krammer (1997), LangeBertalot \& Krammer (2000-2003), Houk et al. (2010), Houk et al. (2014) and Hofmann et al. (2013), updated to recent taxonomic nomenclature using current publications and databases. Thin, needle-shaped Fragilaria nanana was mainly preserved in fragments. Therefore, the lengths of the fragments were measured, summed and divided by the medium length of the intact valves.

Changes in the ratio between benthic + epiphytic and planktic diatom species (B:P ratio) were used to track past changes in the depth of the littoral/profundal boundary. This boundary is determined by lake level and water transparency both affecting light availability for benthic growth (Wetzel, 2001; Hofmann et al., 2020). For the quantitative reconstruction of past lake levels of Oberer Soiernsee Hofmann et al. (2020) developed a diatom-inferred depth model based on the depth-distribution patterns of current diatom assemblages. The authors found that the strongest model is based on a weighted-averaging partial-least-square approach (WA-PLS) with two compounds that provides a robust reconstructive relationship between the distribution of diatoms and lake depth $\left(r^{2}=0.56\right.$; RMSEP $=2.55 \mathrm{~m}$ ).

Past surface temperatures ( $\varnothing \mathrm{TSiVa}$ ) were inferred using the novel silicification value ( $\mathrm{SiVa}$ ) developed by Kuefner et al. (2020a). The diatom-temperature transfer function is based on a training set of 43 mountain lakes located in the Northern Calcareous Alps and refers to the negative correlation between the summer surface temperature and the average degree of silicification of the diatom assemblages preserved in surface sediments (Kuefner et al., 2020b).

$$
\begin{aligned}
& \phi \mathrm{TSiVa}\left({ }^{\circ} \mathrm{C}\right)=25,956-4.7155 * \mathrm{SiVa} \\
& \quad(\mathrm{RMSEP}=0.976) .
\end{aligned}
$$

The ratio between Staurosirella pinnata (Ehrenberg) Williams and Round and Staurosira construens var. venter (Ehrenberg) Hamilton ( $\mathrm{P} / \mathrm{V}$ ratio) was used to indicate trends in lake temperatures. While $S$. construens var. venter is reflecting cooler water temperatures, $S$. pinnata is more competitive under warmer growing conditions (Cremer et al., 2001).

Past total phosphors (TP) concentrations were calculated by applying the TP inference model of Lotter et al. (1998) that is based on 68 small lakes (300-2350 m a.s.l.) located in the Swizz Alps. We chose this model as these lakes are also situated in catchments with calcareous lithology and $70 \%$ of the fossil diatoms of Oberer Soiernsee are part of the modern diatom training set.

Diatom concentrations were calculated by the number of microscope fields of view in relation to the amount of dry sediment.

diatoms $/ \mu l=\frac{N \text { total }}{F v} / V c s * V t * D$

$N_{\text {total }}$ is amount of counted diatom valves in total, $F v$ is analysed fields of view, $V_{\mathrm{cs}}$ is volume of one counting square ((volume of dropped diatom dilution * area of one counting square)/area of the cover glass), $V_{\mathrm{t}}$ is total volume of cleaned diatom solution, $D$ is dilution of cleaned diatom material.

Pigment analysis

The sediments of C2 were analysed for sedimentary pigments following the method of Leavitt \& Hodgson (2001). $0.3 \pm 0.065 \mathrm{~g}$ freeze-dried subsamples were filled into $4 \mathrm{ml}$ amber glasses under subdued green 
light, extracted using 99\% acetone (Rotisolv HPLC, Carl Roth, Germany) and stored at $-20^{\circ} \mathrm{C}$ for $24 \mathrm{~h}$. After gently shaking, $2 \mathrm{ml}$ of the extract were filled into $2 \mathrm{ml}$ Eppendorf tubes and centrifuged for $15 \mathrm{~min}$ at 2,000 rpm and $-9^{\circ} \mathrm{C}$ (Heraeus Fresco 17/21, Thermo Fisher Scientific, Schwerte, Germany). Subsequently, $1.0-1.5 \mathrm{ml}$ of the supernatant was filtered through syringes equipped with $0.2 \mu \mathrm{m}$ PTFE filters into $1.5 \mathrm{ml}$ HPLC glasses. The samples were stored at $-80^{\circ} \mathrm{C}$ until analysis. Pigments were identified and quantified by reverse-phase, high-performance liquid chromatography (HPLC, MD-2015 plus, Jasko, Pfungstadt, Germany) and measured by $436 \mathrm{~nm}$ and $450 \mathrm{~nm}$ detectors, based on Wright et al. (1991). Pigment concentrations were related to dry weight and translated to $\mu \mathrm{g} \mathrm{g}^{-1}$. Some pigments had to be identified by comparing peak time and spectra with data published in Wright et al. (1991) and then quantified by the peak area $\left(\mathrm{mV} \mathrm{min}^{-1}\right)$. Following Leavitt \& Hodgson (2001) and Buchaca \& Catalan (2008), we used chlorophyll $a$ (chl $a$ ), its derivate pheophytin-a (phe-a), $\beta$-carotene and its degradation product ethyl 8'-beta apocarotenoate as marker pigments for total algal biomass and primary production. Diatoms were identified by the pigments fucoxanthin, diatoxanthin, diadinoxanthin and its degradation product diadinochrome. Chrysophyta were represented by violaxanthin, dinophyta by peridinin and diadinoxanthin/diadinochrome. The population dynamics of the chlorophyta were tracked by chlorophyll $b$ and several carotenoids (lutein, neoxanthin, prasinoxanthin, zeaxanthin). Alloxanthin was selected to track abundances of cryptophyta. Pheophytin-a is a typical pigment for decaying communities (Buchaca \& Catalan, 2008). Therefore, we used the chl $a /$ phe-a ratio to estimate the degree of pigment preservation in the sediments (Tõnno et al., 2019). The ratio between alloxanthin and diatoxanthin was used to track past changes in water column transparency or lake-level fluctuations (Buchaca \& Catalan, 2007).

\section{Stable isotope analysis}

Freeze-dried subsamples were sieved $(250-\mu \mathrm{m}$ mesh size) to eliminate organic macro-remains and only the fine fraction was used for isotopic analysis. Additionally, potential in-lake OM sources (phytoplankton, Chara sp., Potamogeton sp.) and OM sources from the catchment (soil, leaves, pine needles, herbages) were collected, oven-dried $\left(40^{\circ} \mathrm{C}\right)$ and homogenised by sieving (soil) or grinding with a mortar. For robust results, we extended the OM dataset and involved catchment $\mathrm{OM}$ samples from 23 mountain lakes situated in the Northern Alps. For simultaneous organic carbon content (wt\% TOC) and $\delta^{13} \mathrm{C}_{\text {org }}$ analyses, $\sim 2.0 \mathrm{mg}$ material was filled into silver capsules and decalcified with first $5 \%$ and thereafter $20 \%$ hydrochloric acid at $70^{\circ} \mathrm{C}$ on a heating plate. Droplets of the acid were successively added to the sediment in each capsule until no effervescence was observed anymore. After drying, the capsules were closed for subsequent isotope analysis (Mayr et al., 2017). To determine the total nitrogen content (wt $\%$ $\mathrm{TN}$ ), $\delta^{15} \mathrm{~N}$, and total carbon (wt\% TC), $\sim 2.5 \mathrm{mg}$ of bulk sediment was filled into tin capsules. Samples were combusted in an element analyser (NC 2500, Carlo Erba) coupled to a continuous-flow, isotoperatio mass spectrometer (Delta Plus, Thermo-Finnigan, Germany) at Friedrich-Alexander-University of Erlangen. Isotope ratios are presented in $\delta$-notation $\left(\delta^{15} \mathrm{~N}, \delta^{13} \mathrm{C}_{\mathrm{org}}\right)$ as $\delta=\left(R_{\mathrm{S}} / R_{\mathrm{St}}-1\right)$, with $R_{\mathrm{S}}$ and $R_{\mathrm{St}}$ as isotope ratios of the sample with the international standards VPDB (carbon) and AIR (nitrogen) and were quoted in \%o. An internal laboratory standard (peptone with $\delta^{15} \mathrm{~N}=4.93 \%$, $\delta^{13} \mathrm{C}_{\text {org }}=-23.80 \%$ ) and international standards (IAEA-N-1; IAEA-N-2; USGS41; IAEA-CH-7; Brand et al., 2014) were used for isotope calibration. Analytical precision (one standard deviation) was typically $0.1 \%$ for both $\delta^{15} \mathrm{~N}$ and $\delta^{13} \mathrm{C}_{\text {org }}$. Elemental contents of total carbon (TC), total organic carbon (TOC), total inorganic carbon (TIC) and total nitrogen (TN) were calculated from the ratios of peak area to sample weight using elemental standards (atropine, cyclohexanone-2.4dinitrophenylhydrazone) for calibration and are shown as mass percentages (wt $\%)$. TOC/TN ratios are expressed as molar ratios.

Analysis of pore water $\mathrm{pH}$ value

Sediment pore water was sampled from core C3 directly in the field using Rhizon SMS $10 \mathrm{~cm}$ core solution samplers $(2.5 \mathrm{~mm}$ diameter, $0.15 \mu \mathrm{m}$ mean pore size; Eijkelkamp Soil and Water, Giesbeek, The Netherlands). A total of eight 3-mm-diameter holes were drilled through the tube wall of the closed core using a gimlet. Saturated Rhizon samplers were inserted horizontally into the sediment through the 
holes. $10 \mathrm{ml}$ syringes (Eijkelkamp Soil and Water, Giesbeek, The Netherlands) were then luer-locked with the Rhizon samplers. The pistons of the syringes were fully withdrawn and held in position with a wooden retainer to generate a vacuum for pore water extraction. Pore water then passed from the sediment through the porous tubes and flexible hoses into the syringes. After $3 \mathrm{~h}$, the Rhizons obtained a sufficient amount of pore water and the $\mathrm{pH}$ could be measured (Multi 3630 IDS, WTW, Weilheim, Germany).

\section{Statistical analyses}

Broken-stick models (Bennet, 1996) were calculated with the R package 'rioja' (Juggins, 2018) to detect the stratigraphic position of major changes of diatom assemblages, pigment compositions and stable isotope records. PAST (version 3.18) statistical software package (Hammer \& Harper, 2006) was used for ecological analyses of life form and substrate preferences. Species abundances were Hellinger transformed (Legendre \& Gallagher, 2001) before analysis. Square-root transformed diatom data was imported in a diatom-inferred depth model (Hofmann et al., 2020) and diatom-inferred TP inference model (Lotter et al., 1998) using R (version 3.4.3) and the package rioja (Juggins, 2018). Diversity was calculated by the Shannon Index using In (natural logarithm) of percentage of each taxon. Down-core profiles were illustrated using C2 version 1.7.7. (Juggins, 2007), including only diatom species with relative abundances greater than $1 \%$ in at least two subsamples. As diatoms were very scarce in core depths greater than $22 \mathrm{~cm}(<50$ valves per sample), the subsamples C2_22 and C2_23 were not included in diatom statistical studies and stratigraphic illustration.

\section{Results}

Sedimentology, core chronology, sedimentation rate and correlation of the cores

The sediment of Oberer Soiernsee mainly consisted of dark grey, partly organic-rich clay and silty clay, interrupted by clearly visible light grey silt layers (Fig. 2).

Two ${ }^{137}$ Cs peaks occurred in the sediments of core C1. Assuming that the ${ }^{137} \mathrm{Cs}$ peak at $1.5 \mathrm{~cm}$ corresponds to the Chernobyl disaster in AD 1986, the sedimentation rate has been very low during recent times $\left(0.05 \mathrm{~cm}\right.$ year $\left.^{-1}\right)$. Since this does not correlate with our results of a stable isotope and pigment analysis that indicate enhanced in-lake productivity, we attributed this to the use of floristic foam to seal the core after sampling, as it destroys the topmost core section. A sedimentation rate of $0.087 \mathrm{~cm}_{\text {year }}{ }^{-1}$ could be calculated from the distance between the first and the second peak at $3.5 \mathrm{~cm}$ (1963). A very similar mean sedimentation rate was estimated using the CRS model (constant rate of supply) on ${ }^{210} \mathrm{~Pb}$ activity $\left(0.084 \mathrm{~cm} \mathrm{year}^{-1}\right)$.

It is reasonable to interpret the light grey silt layers (C1: $11 \mathrm{~cm}, 13 \mathrm{~cm}, 16 \mathrm{~cm}$ and $20 \mathrm{~cm}$ ) as flood layers resulting from fast deposition events such as debris flows and high surface runoffs, especially based on elevated TIC values. Hence, they were removed from the sedimentary record when developing the agedepth model.

Core C2 was obtained two years after the master core. The core was complete and undisturbed (Fig. 2). The comparison of the $\delta^{13} \mathrm{C}_{\text {org }}$ records of both cores reveals a high inter-core consistency. Three event layers of $\mathrm{C} 1(11 \mathrm{~cm}, 13 \mathrm{~cm}$ and $16 \mathrm{~cm})$ were found to correspond exactly in their thickness and sequence with event layers of C2 $(17 \mathrm{~cm}, 19 \mathrm{~cm}$ and $22 \mathrm{~cm})$. Another time marker is represented by the $\sim 3 \mathrm{~cm}$ thick event layer at the top of $\mathrm{C} 2$, which is the result of a strong thunderstorm in August 2015 with extreme rainfall and mud flows. By correlating the $\delta^{13} \mathrm{C}_{\text {org }}$ records and event layers, the chronology of $\mathrm{C} 2$ was found to date back to $\sim \mathrm{AD} 1840$.

Diatom analysis results

\section{Diatom biostratigraphy}

A total of 125 diatom taxa representing 39 genera were identified in 21 subsamples, 21 of these occurred in relative abundances $>2 \%$ in at least two samples (Fig. 3A). Benthic life forms dominated the diatom assemblages, especially fragilarioid species of the genera Pseudostaurosira, Staurosira and Staurosirella, which accounted for $41 \%$ of the total subfossil assemblages. Centric diatoms reached a total abundance of $6 \%$ and were mainly represented by Pantocsekiella comensis Grunow in van Heurck (3\%), Cyclotella cf. woltereckii Hustedt (3\%), and 


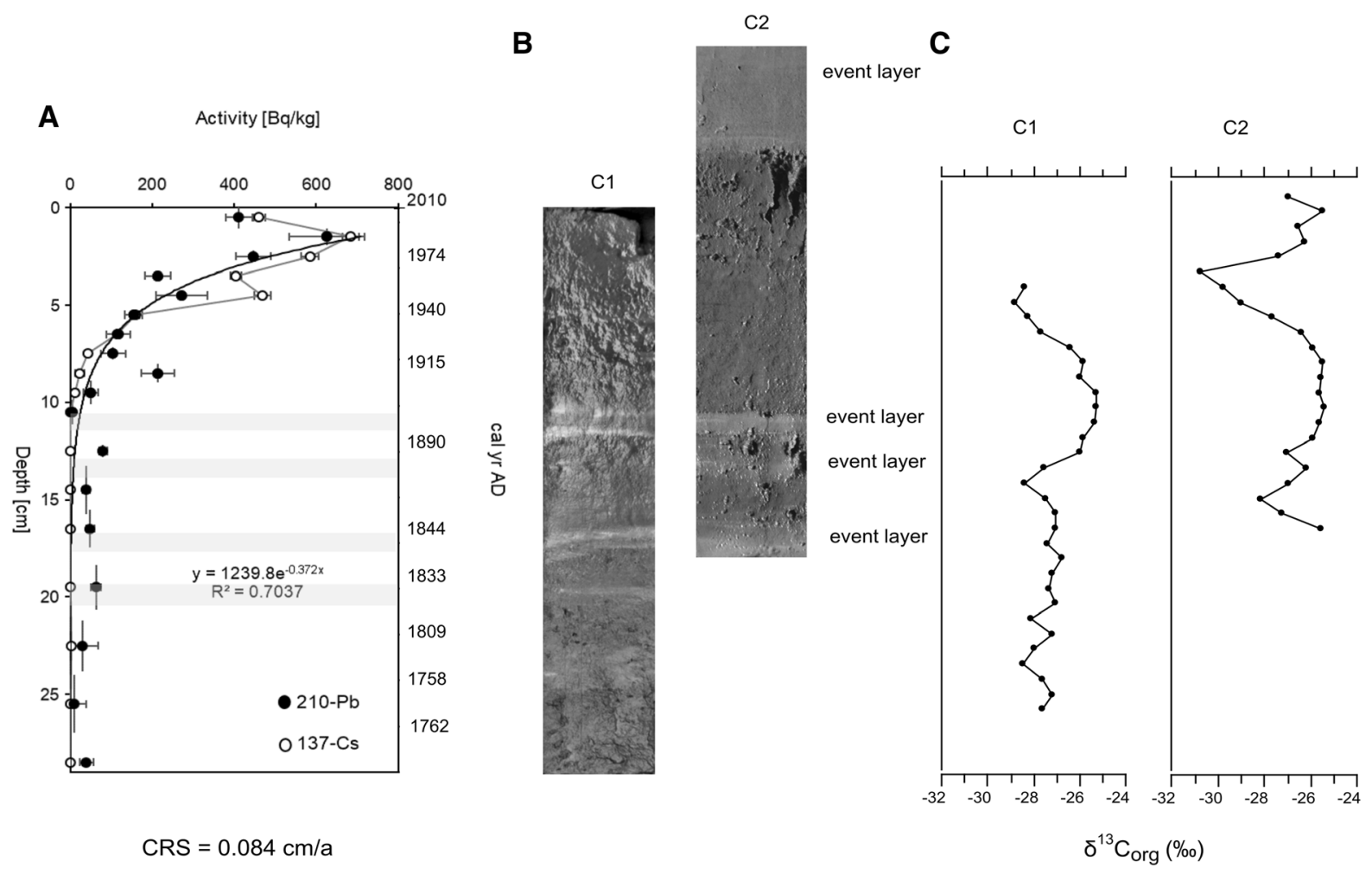

Fig. 2 CRS depth-age model of core $\mathrm{C} 1$ using activity of unsupported ${ }^{210} \mathrm{~Pb}$ (black dots) and ${ }^{137} \mathrm{Cs}$ (white dots) (A). Photos of both cores and position of event layers $(\mathbf{B})$. Correlation of $\mathrm{C} 1$ and $\mathrm{C} 2$ via $\delta^{13} \mathrm{C}_{\text {org }}$ records $(\mathbf{C})$

Cyclotella praetermissa Lund (1\%). Overall, the most frequent periphytic taxa were S. pinnata (28\%), Amphora pediculus (Kützing) Grunow (26\%), S. construens var. venter (6\%), Denticula tenuis Kützing (4\%), Achnanthidium straubianum (Lange-Bertalot) Lange-Bertalot (3\%), Achnanthidium minutissimum var. minutissimum (Kützing) Czarnecki (2\%), F. nanana Lange-Bertalot (2\%), Platessa conspicua (A. Mayer) Lange-Bertalot (2\%), Pseudostaurosira elliptica (Schumann) Edlund, E. Morales, S.A. Spauld (2\%), Pseudostaurosira trainorii E. Morales (2\%), and Amphora inariensis (Krammer) Lange-Bertalot (2\%). Species richness varied between 20 and 55, Shannon diversity between 1.8 and 2.8 (Fig. 3B). The total diatom concentrations in the sediment samples ranged from $5 \times \cdot 10^{2}$ to $2 \times \cdot 10^{4}$ diatoms $\mu \mathrm{l}^{-1}$ (Fig. 3B).

The broken-stick model (Bennet, 1996) identified four different diatom assemblage zones (Fig. 3A, B).

Zone D-A (21-18 cm; AD 1856-1880) Amphora pediculus and $S$. pinnata co-dominated the diatom assemblages of the deepest diatom zone. Fragments of Aulacoseira spp. occurred frequently in this zone.

Zone $\quad D-B \quad(18-6 \mathrm{~cm} ; \quad A D \quad 1880-2010)$ The assemblages of this zone differ clearly from those of zone D-A, although $A$. pediculus and $S$. pinnata remained the dominant taxa. After a peak in AD 1960, $S$. construens var. venter declined in frequency. Pseudostaurosira elliptica disappeared around $\mathrm{AD}$ 1960, when $P$. trainorii clearly increased in its abundances.

Zone D-C (6-2 cm; AD 2010-2015) Beside A. pediculus and $S$. pinnata, $P$. conspicua dominated the diatom assemblages. Centric diatoms and $F$. nanana started to increase distinctly in their abundances. The abundances of $S$. construens var. venter clearly decreased towards the end of the zone, while $S$. pinnata increased slightly.

Zone D-D (2-0 cm; AD 2015-2017) Centric diatoms (31-65\%) and F. nanana (8-22\%) co-dominated the 

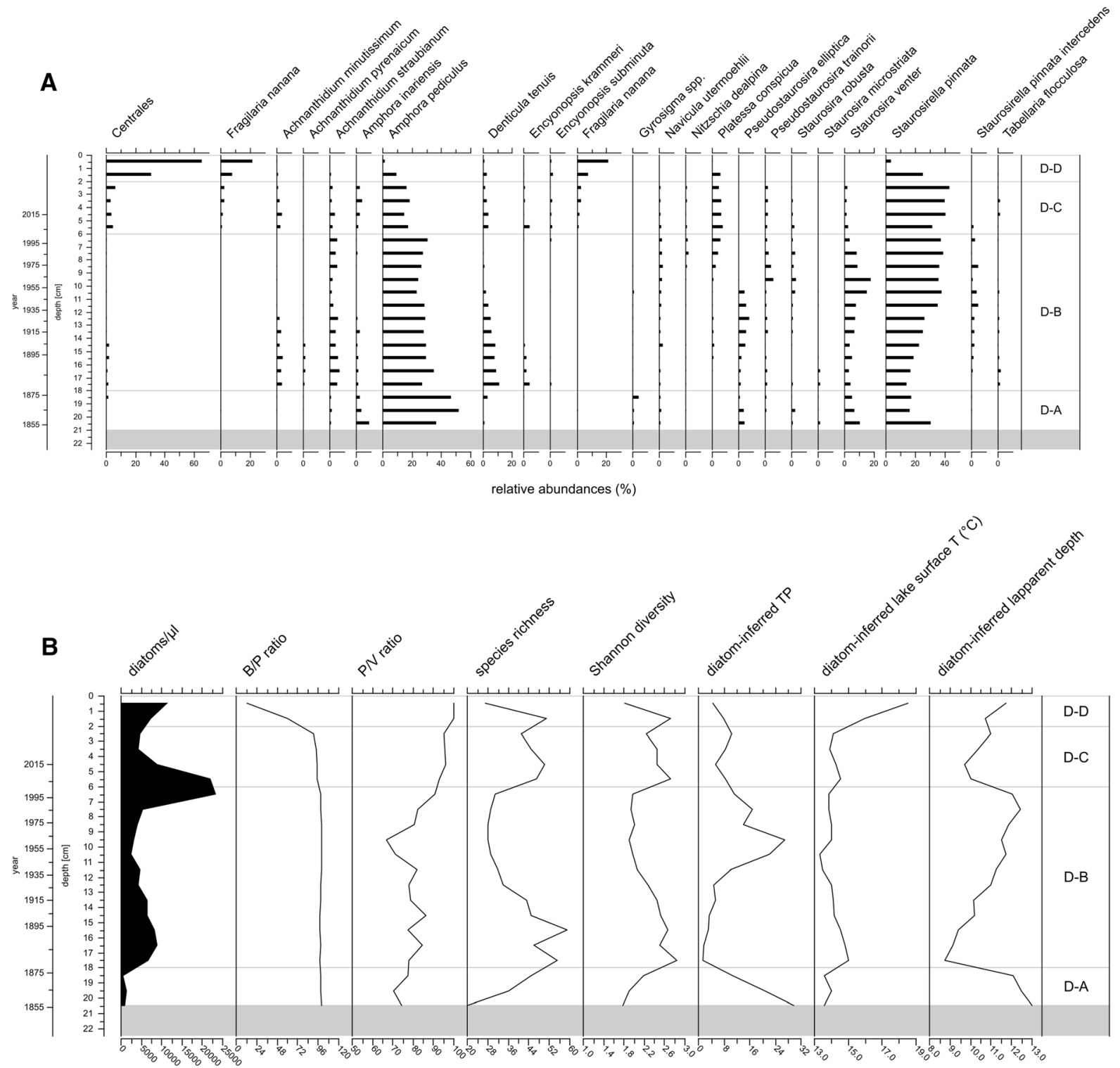

Fig. 3 A Diatom stratigraphy of most common taxa with abundances $>2 \%$ in at least two samples. The four diatom zones (D-A to D-D) are separated by grey lines. B Variation in the ratios between benthic + epiphytic and planktic taxa (B/P ratio) and between Staurosirella pinnata and Staurosira construens var. venter ( $\mathrm{P} / \mathrm{V}$ ratio). Alteration of Shannon diversities and species richness. Reconstruction of lake

assemblages of this zone. Small $P$. comensis in particular is highly abundant (1-30\%). Simultaneously, all periphytic taxa clearly declined. All small fragilarioid taxa were absent with the exception of S. pinnata. temperature using the silicification value (Kuefner et al., $2020 \mathrm{a}, \mathrm{b})$, of lake depth by applying the model designed by Hofmann et al. (2020) and of TP using the model of Lotter et al. (1989). The four diatom zones (D-A to D-D) are separated by grey lines. The grey bar represents the two lowermost samples, where diatoms were too scare for including in statistical analyses

The valve density (Fig. 3B) was very low in the deeper part of the core (zone D-A), but clearly increased after $\mathrm{AD}$ 1880. A distinct maximum was calculated in the transition between zones D-B and D-C (7.5-5.5 cm; AD 1986-2010). After this, the cell 
density declined visibly before it increased again in the younger sediments (2.5-0.5 cm; AD 2015-2017).

The ratio between benthic + epiphytic and planktic diatom species (B:P ratio; Fig. 3B) showed only small variations before $\mathrm{AD}$ 2010, but declined markedly in zone D-D. After the distinct dominance of benthic diatoms in the deepest sample, planktic taxa gained importance between AD 1870 and AD 1900, which is also reflected in the increasing species richness and diversity. Between $\mathrm{AD} 1940$ and $\mathrm{AD}$ 2000, epipsammic fragilarioid taxa clearly dominated the periphytic (benthic + epiphytic) diatom assemblages, while centric, epilithic and epiphytic species occurred in low percentages, resulting in low species richness and Shannon diversities. Zone D-C is characterised by higher diversity indices and more diverse periphytic diatom assemblages. The B:P ratio decreased due to increasing abundances of centric diatoms. The distinct dominance of planktic species in zone D-D resulted in low B:P ratios and decreasing diversity indices.

The ratio between S. pinnata and S. construens var. venter ( $\mathrm{P}: \mathrm{V}$ ratio; Fig. 3B) generally increased towards recent times. Whereas the ratio varied around a median of 78 between 21.5 and $7.5 \mathrm{~cm}$, it clearly increased after $\sim \mathrm{AD} 1980$ to a median of 95.6, implying the declining influence of $S$. construens var. venter in zones D-C and D-D.

\section{Diatom-based reconstruction of lake surface temperatures, lake levels, and TP concentrations}

By calculating the lake surface temperatures using the silicification value (Kuefner et al., 2020a, b), there is clear evidence of a trend towards rising temperatures from $13.6^{\circ} \mathrm{C}(\sim \mathrm{AD} 1856)$ to $18.5^{\circ} \mathrm{C}$ ( $\left.\mathrm{AD} 2017\right)$ (Fig. 3B). The diatom assemblages of the deepest diatom zone (D-A) indicated the lowest mean surface temperature $\left(13.9^{\circ} \mathrm{C}\right)$. Increasingly higher average surface temperatures were calculated for the diatom assemblages of the zones D-B $\left(14.0^{\circ} \mathrm{C}\right), \mathrm{D}-\mathrm{C}\left(14.2^{\circ} \mathrm{C}\right)$, and D-D $\left(17.2^{\circ} \mathrm{C}\right)$.

By applying the diatom-inferred depth model designed by Hofmann et al. (2020), the WA-PLS $\left(\mathrm{RMSE}=2.43 \mathrm{~m} ; r^{2}=0.63\right)$ approach proved to be suitable. The reconstructed lake levels show a first maximum $(12.5 \pm 2.4 \mathrm{~m})$ around $\mathrm{AD} 1868$ and $\mathrm{a}$ second maximum $(12.5 \pm 2.4 \mathrm{~m})$ around $\mathrm{AD} 1986$ (Fig. 3B). Inferred depth values steadily increased between $A D 1880$ and $A D$ 1986. Subsequently the value declined to a second minimum $(9.7 \pm 2.4 \mathrm{~m})$ in 2015 , before the increased again up to $11.7 \pm 2.4 \mathrm{~m}$ in $\mathrm{AD}$ 2017 (Fig. 3B).

TP reconstructions (WA-PLS approach; RMSE = $\left.0.27 ; r^{2}=0.75\right)$ using the model of Lotter et al. (1998) revealed a maximum $29.9 \pm 1.9 \mu \mathrm{g}^{-1}$ around AD 1860. TP concentrations fist declined, and then started to rise after AD 1890. After a second maximum $\left(27 \pm 1.9 \mu \mathrm{g} \mathrm{l}^{-1}\right)$ around $\mathrm{AD} 1965$ the values tended to decrease to $8.4 \pm 1.9 \mu \mathrm{g}^{-1}$ around AD 2015. Within the event layer mean TP concentrations $\sim 8.0 \pm 1.9 \mu \mathrm{g} \mathrm{l}^{-1}$ were inferred. In the uppermost sample $\mathrm{TP}=4.5 \pm 1.9 \mu \mathrm{g} \mathrm{l}^{-1} \quad$ was reconstructed (Fig. 3B).

\section{Sedimentary pigment analyses}

Five different phases with regard to pigment concentration and preservation could be distinguished (Fig. 4).

Phase P-A (22.5-16.5 cm; before AD 1880) was characterised by low chl $a$ and $\beta$-carotene concentrations and low chl $a /$ phe-a ratios, indicating low algal biomass and poor pigment preservation. Two clearly visible declines in all pigment concentrations at $16.5 \mathrm{~cm}$ and $18.5 \mathrm{~cm}$ are noticeable. The high concentrations of diadinochrome, a derivate of diadinoxanthin, suggest the dominance of periphytic diatoms in the outgoing nineteenth century.

Significantly higher concentrations of nearly all pigments and higher chl $a /$ phe-a ratios were detected during phase P-B1 (15.5-9.5 cm; AD 1890-1960), suggesting an increasing total algae biomass and rising pigment preservation. However, a decrease in chl $a$ and $\beta$-carotene concentrations are evident towards the end of phase P-B1.

Phase P-B2 (8.5-7.5 cm; AD 1970-1986) started with low preservation ratios and a depression of total algal biomass marker concentration. However, the concentrations of most pigments began to increase within this phase. After a maximum around AD 1970, violaxanthin (Chrysophyta) disappeared abruptly.

Since $\sim$ AD 1990 (phase P-C; 6.5-5.5 cm), there has been a dramatic increase in total algal biomass and a steady, up to threefold rise in preservation ratios. Peridin (Dinophyta), alloxanthin (Cryptophyta) and the marker pigments of green algae (chlorophyll $b$, 


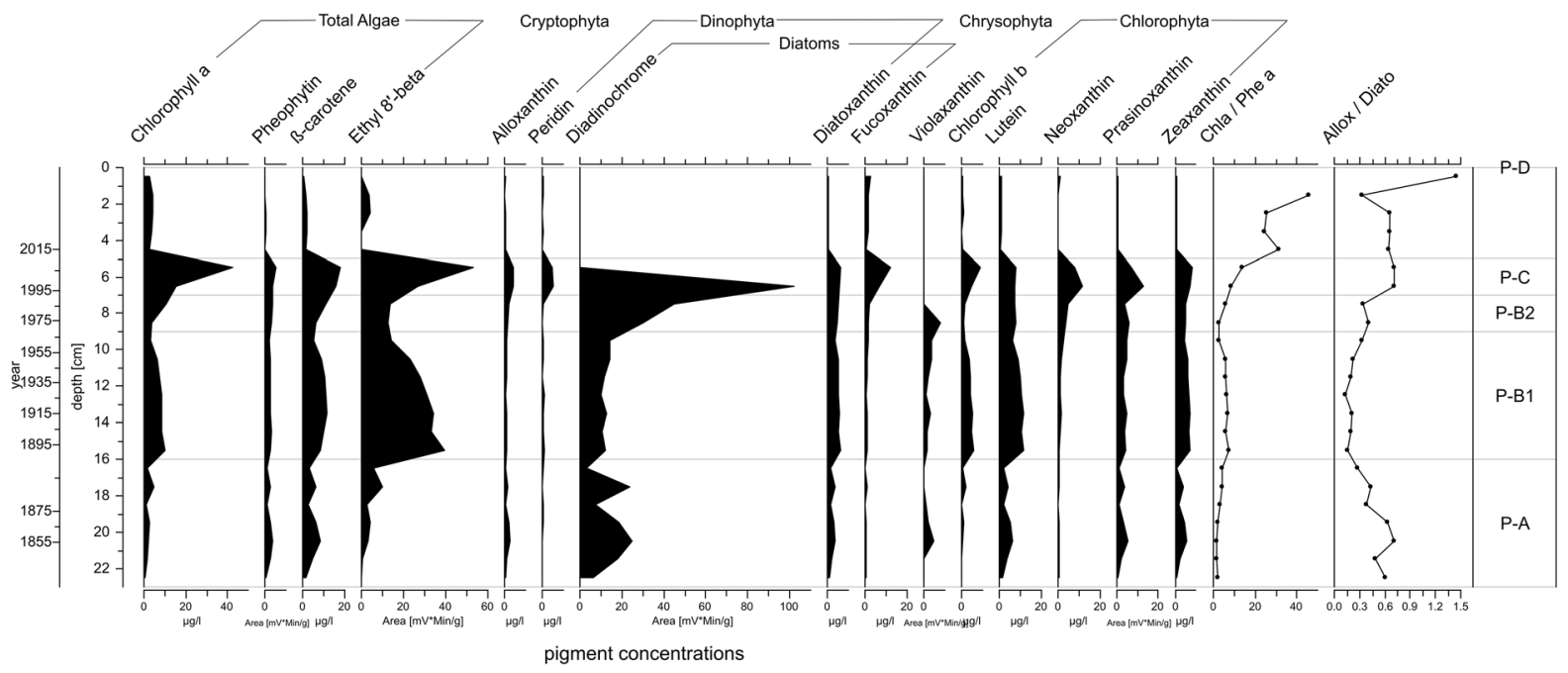

Fig. 4 Sedimentary record of the marker pigments, of the pigment preservation ( $\mathrm{Chl} a / \mathrm{Phe}$ a) and of the ratio between alloxanthin and diatoxanthin (Allox/Diato). The five pigment zones (P-A to P-D) are separated by grey lines

neoxanthin, prasinoxanthin and zeaxanthin) appeared in their highest concentrations.

Between AD 2015 and AD 2017 (4.5-0.5 cm; phase P-D), the preservation ratios increased markedly by a factor of 10. Simultaneously, the concentrations of all pigments decreased abruptly.

Stable isotopes analysis

\section{Organic geochemistry and stable isotopes of the sediments}

Four different phases could be separated in terms of organic geochemistry and stable isotope ratios (Fig. 5).

Phase SI-A (22.5-20.5 cm; before AD 1868) began with high values of $\delta^{13} \mathrm{C}_{\mathrm{org}}(-25.5 \%)$ and TIC (9.4 wt $\%)$, followed by a marked decrease towards the end of the zone. TOC (3.1 wt\%), TN $(0.3)$ and $\delta^{15} \mathrm{~N}$ $(1.9 \%$ ) exhibited low values at the base of the core and increased distinctly higher up. $\delta^{15} \mathrm{~N}$ showed the highest values $(2.6 \%)$ and TIC (4.9 wt $\%)$ the lowest values of the entire record at $20.5 \mathrm{~cm}(\sim \mathrm{AD} 1860)$. The highest TOC/TN ratio of the entire record (10.2) occurred at $22.5 \mathrm{~cm}$.

$\delta^{13} \mathrm{C}_{\mathrm{org}}$ and TIC values initially rose during phase SI-B (19.5-8.5 cm; AD 1868-1980), accompanied by declining TOC and TN contents. Subsequently, between AD 1890 and AD 1950, hardly any changes were visible for the TN (median 0.4 wt $\%$ ), $\delta^{13} \mathrm{C}_{\mathrm{org}}$ (median - 26.6\%o), TOC (median $3.8 \mathrm{wt} \%$ ) and TIC (median $9.2 \mathrm{wt} \%$ ) values. Only $\delta^{15} \mathrm{~N}$ (median $1.5 \%$ ) exhibits greater fluctuations, especially before $\mathrm{AD}$ 1890. $\delta^{15} \mathrm{~N}$ values began to decline after $\sim \mathrm{AD}$ 1960. From $\mathrm{AD} 1940$ onwards, $\delta^{13} \mathrm{C}_{\text {org }}$ and TIC decreased steadily, while TOC and TN increased towards the end of the phase.

Phase SI-C (7.5-5.5 cm; AD 1980-2015) is characterised by several prominent changes: there was a marked drop in $\delta^{13} \mathrm{C}_{\text {org }}$ down to a minimum of $30.8 \%$ at $5.5 \mathrm{~cm}$ and a concurrent increase in TOC and TN up to a maximum of $6.1 \mathrm{wt} \%$ and $0.9 \mathrm{wt} \%$, respectively. The TOC/TN ratio also reached a distinct minimum at $5.5 \mathrm{~cm}$ (6.9).

During phase SI-D (4.5-0.5 cm; AD 2015-2017), $\delta^{13} \mathrm{C}_{\text {org }}$ shifted again to higher values (up to $-25.5 \%$ at $1.5 \mathrm{~cm}$ ). TOC showed the lowest contents during the entire investigation period (2.5-2.6 wt $\%)$. TIC increased markedly to the highest values (10.4-11.6 wt $\%)$. TN had the lowest values $(0.3 \mathrm{wt} \%)$ comparable to values at the base of the core.

\section{Isotopic and geochemical signatures of OM sources and the origin of sedimentary $O M$}

The isotopic signatures of modern OM (lake algae, herbaceous vegetation, terrestrial soils, trees and submerged macrophytes) collected in the lake and in its catchment are shown in Table 1. Based on modern isotopic fingerprints, algae appeared to be the main 


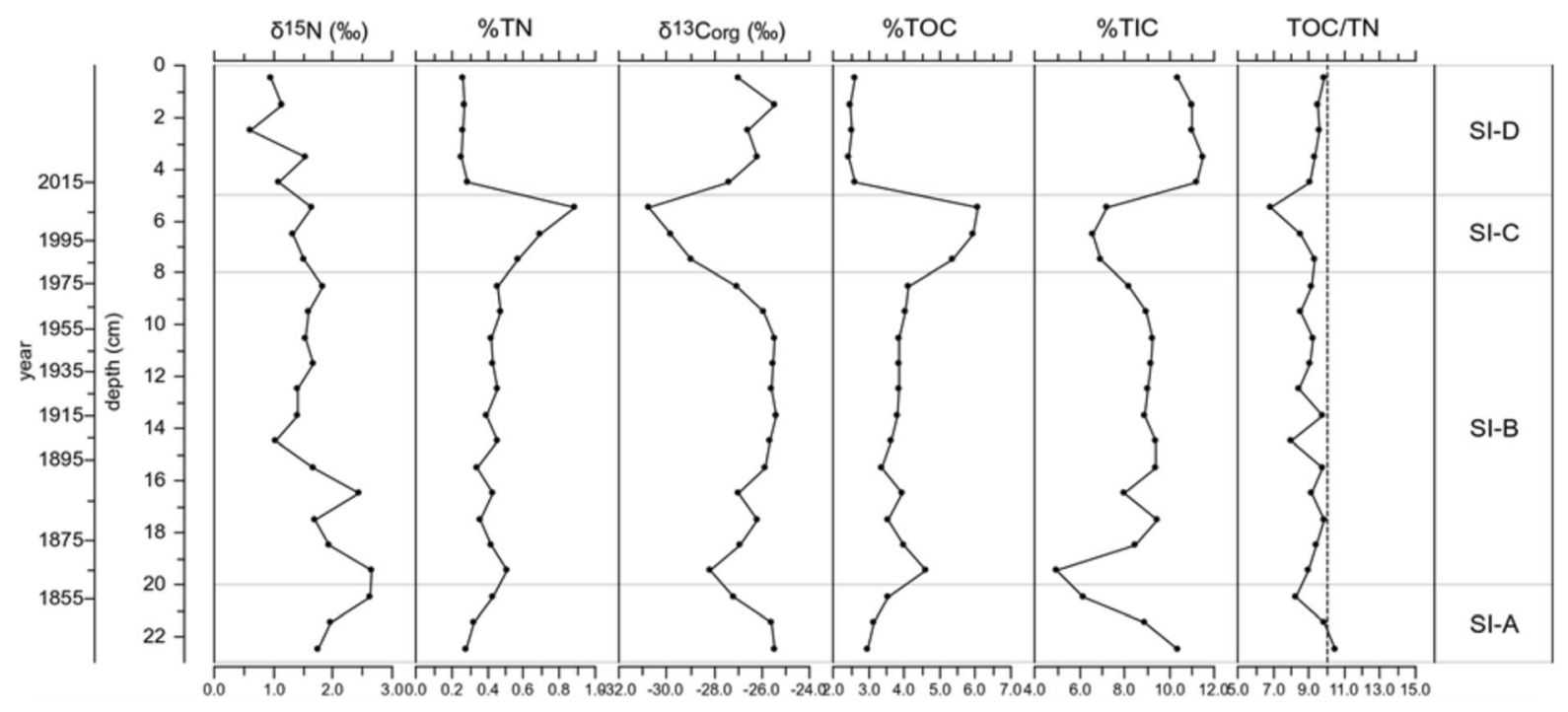

Fig. 5 Stable isotope $\left(\delta^{13} \mathrm{C}_{\mathrm{org}}, \delta^{15} \mathrm{~N}\right)$, geochemical (TN, TOC, TIC and TOC/TN data of sedimentary organic matter. The four phases (SI-A to SI-D) are separated by grey lines

Table 1 Isotopic signatures of modern OM sources including macrophytes, lake algae and catchment soils and vegetation

\begin{tabular}{|c|c|c|c|}
\hline $\begin{array}{l}\text { Modern OM } \\
\text { source }\end{array}$ & $\delta^{13} \mathrm{C}_{\mathrm{org}}$ & $\delta^{15} \mathrm{~N}$ & TOC/TN \\
\hline Lake algae & $\begin{array}{l}\text { Median }-28.4 \% \text {, (range } \\
\text { between }-34.9 \text { and }-19.8)\end{array}$ & $\begin{array}{l}\text { Median } 3.6 \% \text { (range between } 1.2 \text { and } \\
5.4 \text { ) }\end{array}$ & $\begin{array}{l}\text { Median } 9.0 \text { (range between } 6.9 \\
\text { and 10.2) }\end{array}$ \\
\hline $\begin{array}{l}\text { Herbaceous } \\
\text { vegetation }\end{array}$ & $\begin{array}{l}\text { Median }-28.9 \% \text {, (range } \\
\text { between }-30.5 \text { and }-26.6 \% \text { ) }\end{array}$ & $\begin{array}{l}\text { Median }-1.18 \% \text {, (range } \\
\text { between }-3.6 \text { and } 0.8 \% \text { ) }\end{array}$ & $\begin{array}{l}\text { Median } 18.2 \text {, range (between } \\
12.2 \text { and } 30.7 \text { ) }\end{array}$ \\
\hline Terrestrial soils & $\begin{array}{l}\text { Median }-26.9 \% \text { (range } \\
\text { between }-27.3 \text { and }-26.5)\end{array}$ & $\begin{array}{l}\text { Median }-1.6 \% \text { (range } \\
\text { between }-3.5 \text { and } 0.6 \% \text { ) }\end{array}$ & $\begin{array}{l}\text { Median } 15.8 \text { (range between } \\
11.4 \text { and } 18.2 \text { ) }\end{array}$ \\
\hline Conifers & $\begin{array}{l}\text { Median }-28.8 \% \text {, (range } \\
\text { between }-30.8 \text { and }-26.8 \% \text { ) }\end{array}$ & $\begin{array}{l}\text { Median }-4.4 \% \text {, (range } \\
\text { between }-9.2 \text { and }-1.0 \% \text { ) }\end{array}$ & $\begin{array}{l}\text { Median 44.1, (range between } \\
27.1 \text { and 55.6) }\end{array}$ \\
\hline Deciduous trees & $\begin{array}{l}\text { Median }-29.4 \% \text {, (range } \\
\text { between }-32.7 \text { and }-26.4 \% \text { ) }\end{array}$ & $\begin{array}{l}\text { Median } 3.1 \% \text {, (range between }-5.4 \\
\text { and } 0.31 \% \text { ) }\end{array}$ & $\begin{array}{l}\text { Median } 20.5 \text {, (range between } \\
14.2 \text { and } 33.2 \text { ) }\end{array}$ \\
\hline $\begin{array}{l}\text { Potamogeton } \\
\text { alpinus }\end{array}$ & $-13.6 \%$ & $2.0 \%$ & 9.8 \\
\hline Chara spp. & $-17.8 \%$ & $-7.9 \%$ & 9.0 \\
\hline
\end{tabular}

source of sedimentary OM (Fig. 6). Additionally, terrestrial soils contributed to sedimentary OM (Fig. 6). A proportion of sedimentary OM derived from macrophytes, herbaceous vegetation and trees, both coniferous and deciduous is very unlikely as their isotope signatures plot at a large distance to the sediment signatures (Fig. 6).

\section{Linkages between carbon and nitrogen cycles}

Findlay \& Kendall (2007) summarised the main geochemical processes controlling $\delta^{15} \mathrm{~N}$ and $\delta^{13} \mathrm{C}_{\text {org }}$ of aquatic $\mathrm{OM}$ under the premise of a predominant algal origin of OM (Fig. 6). The TOC/TN ratios in the sediments of Oberer Soiernsee revealed that algae are the major sedimentary OM component, as pure algal matter typically ranges between 7 and 9 (Meyers \& Teranes, 2001). Accordingly, photosynthesis and eventually methane oxidation are the main factors 

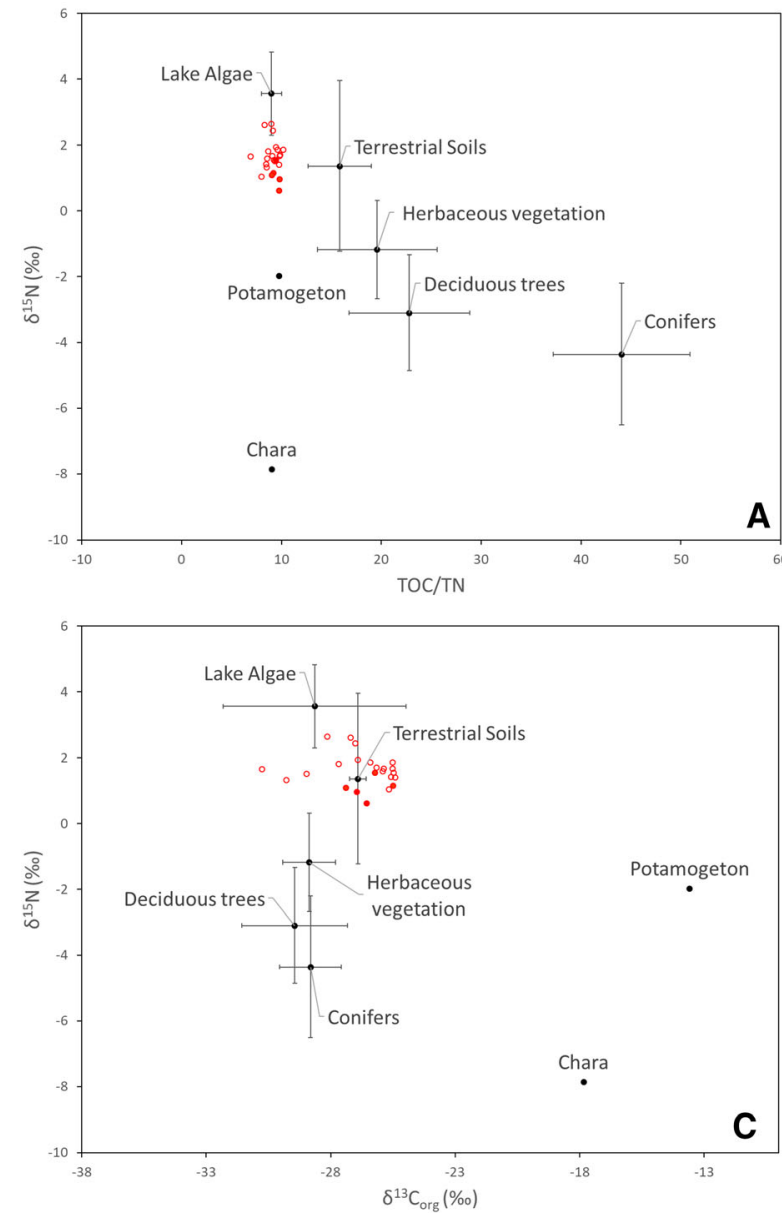

Fig. 6 Isotopic and geochemical signatures of sediment record (red open circles) and potential sources of sedimentary OM. Red dots represent most recent samples (AD 2017-2017) (A-C). $\delta^{15} \mathrm{~N}$

that regulated changes in $\delta^{13} \mathrm{C}_{\mathrm{org}}$ records in Oberer Soiernsee (Fig. 6). The variations in $\delta^{15} \mathrm{~N}$ are smaller than those in $\delta^{13} \mathrm{C}_{\mathrm{org}}$ record and may point to denitrification. Before the $\mathrm{AD} 1860$ s (red dots), an increasing $\delta^{15} \mathrm{~N}$ (positive shift of $0.8 \%$ ) and simultaneously decreasing $\delta^{13} \mathrm{C}_{\mathrm{org}}$ (negative shift of 2.6\%) indicated a combination of incipient denitrification and methane oxidation processes (Fig. 6). Between 1870 and 1980 (green dots), a marked shift towards $1.4 \%$ lower $\delta^{15} \mathrm{~N}$ values and $1.4 \%$ o higher $\delta^{13} \mathrm{C}_{\text {org }}$ values suggests elevated primary production. After $\mathrm{AD}$ 1970 the records of $\delta^{15} \mathrm{~N}$ and $\delta^{13} \mathrm{C}_{\text {org }}$ are decoupled. Towards 1980, decreasing $\delta^{13} \mathrm{C}_{\text {org }}$ indicates that respiration or, more likely, anoxic biochemical processes became increasingly important. Between $\mathrm{AD}$ 1980 and $\mathrm{AD} 2015$, a marked negative shift (3.1\%)
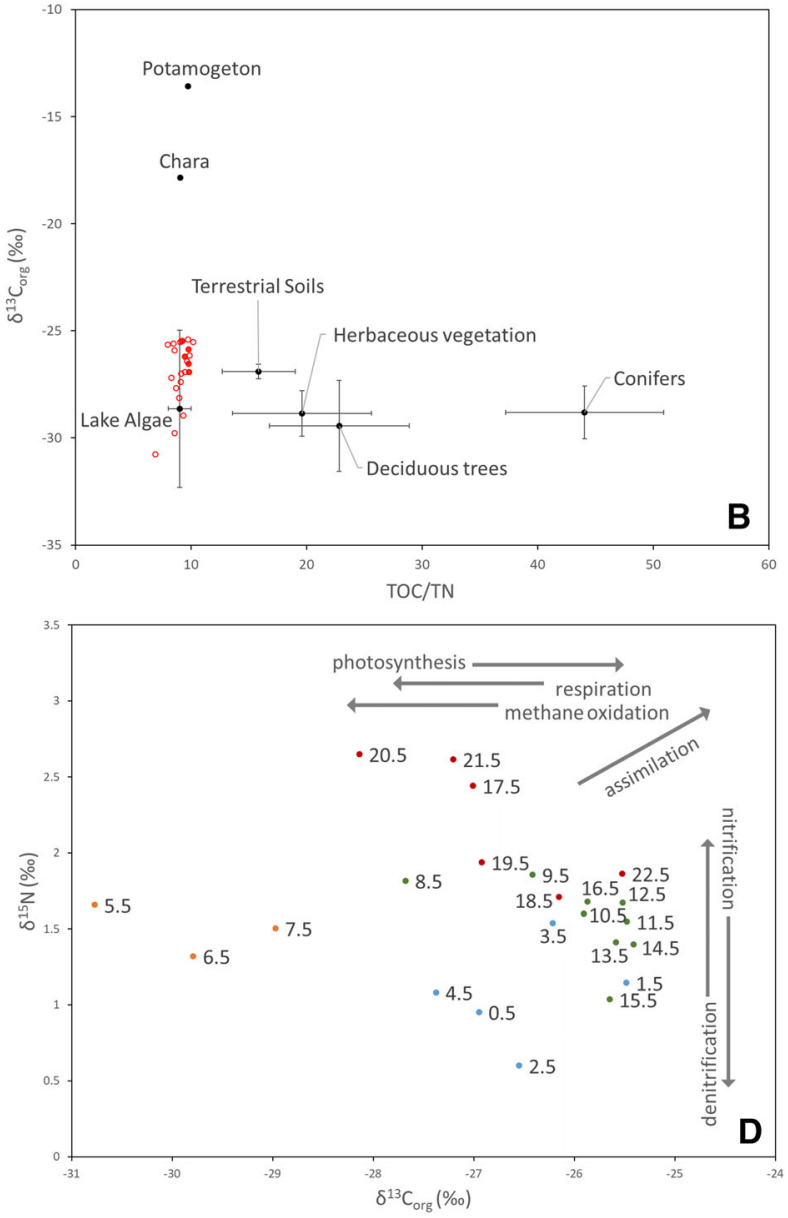

versus $\delta^{13} \mathrm{C}_{\text {org }}$ based on Finlay \& Kendall (2007) to evaluate main geochemical in-lake processes controlling $\delta^{13} \mathrm{C}_{\text {org }}$ and $\delta^{15} \mathrm{~N}$ of aquatic OM (D)

towards significantly lower $\delta^{13} \mathrm{C}_{\mathrm{org}}$ values indicates enhanced methane oxidation processes (orange dots). After $\mathrm{AD} 2015$ the shift towards higher $\delta^{13} \mathrm{C}_{\text {org }}$ values indicate enhanced photosynthesis and possibly nitrification as important processes (blue dots).

Table $2 \mathrm{pH}$ values of the sediment-water interface and of the sediment pore water in specific depths

\begin{tabular}{lllllll}
\hline Sediment depth $(\mathrm{cm})$ & 0 & 2 & 6 & 10 & 16 & 20 \\
$\mathrm{pH}$ & 8.6 & 7.8 & 7.7 & 7.5 & 7.5 & 7.4 \\
\hline
\end{tabular}


In situ pore water $\mathrm{pH}$ analysis $(\mathrm{C} 3)$

The $\mathrm{pH}$ value at the sediment-water interface was 8.6 in October 2018. Down-core, the values declined continuously from $7.8(2 \mathrm{~cm})$ to $7.4(20 \mathrm{~cm})$ (Table 2).

\section{Discussion}

The combination of sedimentological, biological, biochemical and geochemical proxies, supported by historical information, proved as a powerful tool to reconstruct the ecological history of Oberer Soiernsee and to disentangle the effects of different environmental impacts on the lake evolution since $\sim \mathrm{AD}$ 1840. Diatom, pigment and $\delta^{13} \mathrm{C}$ records provided valuable information on the effects of catchmentrelated changes on lake-internal biogeochemical processes. Chl $a$ and $\delta^{13} \mathrm{C}$ show very similar trends, facilitating the reconstruction of lake trophic history reliably. Diatom-inferred TP concentrations, however, show partly distinct differences. Juggins (2013) warns against the uncritical use of quantitative reconstructions, as biotic communities respond sensitively and complexly to multiple environmental gradients. Lotter et al. (1998) conceded that, besides TP a series of other causal factors such as mean summer temperatures, mixing regimes, the availability of light and other nutrients (nitrogen, silica and carbon) and interspecific competition control the composition of the diatom assemblages. The application of transfer functions requires a negligible influence of these secondary environmental variables; furthermore, the effects of temporal change in the underlying causal relationships must be considered (Juggins, 2013).

However, several facets of global environmental changes have affected remote mountain lakes since the industrial revolution (Catalan et al., 2013). The effects these global changes on the lake ecology of Oberer Soiernsee were revealed by the $\delta^{15} \mathrm{~N}$ record (atmospheric deposition-fertilisation) and by shifts in diatom species composition (changes of water temperature, thermal stratification and light availability).

\section{Depth-age model}

The applicability of the CRS model to date the sediments of Oberer Soiernsee may be debatable as the lake was exposed to a series of both catchment- mediated and lake-internal changes resulting in an increase of algae biomass (Figs. 3, 4). However, after discarding the event layers (Fig. 2), our age-depth model correlates well with historical records including land use, hut construction, overnight stays (Müller, 1922; Cabin book of the small private cabin; Yearbooks of the Alpine Club Section Hochland 1920-2017).

\section{Ecological history of Oberer Soiernsee}

\section{Period I (AD 1840-AD 1880): Little Ice Age, alpine pasturing, hut construction}

The high frequency of paleoflood layers in the deeper part of the core (Fig. 1) are indicators for heavy rainfall events (Giguet-Covex et al., 2012; Wilhelm et al., 2012, 2013) and suggest the influence of the Little Ice Age (LIA), a period of low temperatures, high wind speeds and high precipitation that occurred from the sixteenth to the mid-nineteenth century, particularly in the Northern Hemisphere (Bracht-Flyr \& Fritz, 2016; Ilyashuk et al., 2018). TOC/TN ratios $>10$ indicate enhanced allochthonous $\mathrm{OM}$ sources (Meyers \& Teranes, 2001) in particular soils (Fig. 5), due to the enhanced erosion induced by higher precipitation rates in the LIA.

The high flood frequency and the harsh conditions including low temperatures and short growing seasons led to low diatom and pigment concentrations before $\sim$ AD 1850 (Fig. 3A, 4). Post-depositional dissolution of the siliceous diatom valves can be excluded as both heavily (e.g. Diploneis spp., Gyrosigma spp.) and slightly (e.g. Staurosira microstriata) silicified taxa were sporadically found. Furthermore, pore water analyses revealed $\mathrm{pH} 7.4$ (Table 2), suggesting favourable preservation conditions as diatom dissolution especially occurs at pH > 9.0 (Lewin, 1961; Barker et al., 1994).

The large-celled, heavily silicified Aulacoseira species, occurring especially before $\sim \mathrm{AD} 1880$ also indicate more turbulent conditions in context with the LIA, as this species requires turbulent mixing to remain in the photic zone and gain access to nutrient resources (Karst-Riddoch et al., 2005; Reynolds, 2006; Saros \& Anderson, 2014; Weckström et al., 2016; Rühland et al., 2018).

The light availability for benthic growth depends on both water depth and light penetration. Hence, diatom- 
inferred high lake levels before $\sim$ AD 1880 (Fig. 3B) more likely indicate the high-turbid conditions with low water transparency that often prevailed during the windy periods towards the end of the LIA (Mann, 2002a). The high ratios between alloxanthin and diatoxanthin also indicate limited light availability for benthic algae (Fig. 4). In contrast, high $\mathrm{B} / \mathrm{P}$ ratios suggest extensive periphytic diatom growth, especially of small epipsammic fragilarioids and epipelic Amphora spp. (Figs. 3A, B), which are both indicative for the deeper littoral zone of Oberer Soiernsee today (Hofmann et al., 2020). The small epipsammic species are known to live firmly attached on sand grains, to be resistant to abrasion or damage due to a harsh and turbulent environment, and to even tolerate short terms of darkness and brief anaerobic conditions (Moss, 1977; Hofmann et al., 2020). Epipelic taxa have a competitive advantage, as they are able to avoid permanent burial due to their mobility (Moss, 1977; Burkholder, 1996).

Diatom-inferred TP reconstruction fits well with the $\delta^{13} \mathrm{C}_{\text {org }}$ trend. TP $\sim 30 \pm 1.9 \mu \mathrm{g} \mathrm{1^{-1 }}$ revealed mesotrophic conditions around $\mathrm{AD} 1860$ (Fig. 3) also reflected by rising pigment concentrations despite low preservation indices (Fig. 4). We assume that the high erosion rates related to the LIA may be responsible for the elevated TP concentrations, as the calcareous rocks in the catchment may contain considerable amounts of phosphorus-containing minerals (Valeton, 1988). The high TIC values in the deepest part of the core (AD 1840-1860) support this assumption (Fig. 5).

The decline in $\delta^{13} \mathrm{C}_{\text {org }}$ may have been triggered by the gradual ${ }^{13} \mathrm{C}$ depletion of atmospheric $\mathrm{CO}_{2}$ since the industrial revolution. McCaroll \& Loader (2004) found that the combustion of fossil fuels resulted in $1.5 \%$ more negative $\delta^{13} \mathrm{C}_{\text {org }}$ values of atmospheric $\mathrm{CO}_{2}$ as fossil fuels are relatively depleted in ${ }^{13} \mathrm{C}$. The shift to $2.61 \%$ lower $\delta^{13} \mathrm{C}_{\text {org }}$ values (Fig. 5) is, however, too large to be explained solely by a fossil fuel combustion effect. Enhanced external input by an increased flood frequency during the LIA and additionally alpine pasturing and forestry (Müller, 1922) seems to be a more plausible cause for ${ }^{13} \mathrm{C}$ depletion of sedimentary $\mathrm{OM}$ as these activities are known to provide additional nutrient load to the lake and promote lake eutrophication (Schwoerbel \& Brendelberger, 2013). Enhanced primary productivity resulted in hypolimnetic anoxic conditions that promote chemoautotrophic organisms and methanotrophic bacteria with ${ }^{13} \mathrm{C}$-depleted biomass (Braig et al., 2013). These microbes produce ${ }^{13} \mathrm{C}$-depleted $\mathrm{CO}_{2}$ and thus change the DIC reservoir of a lake (Hollander \& Smith, 2001). The resulting ${ }^{13} \mathrm{C}$-depleted photoautotrophic biomass and the ${ }^{13} \mathrm{C}$-depleted microbial biomass culminate in the negative trends in the $\delta^{13} \mathrm{C}_{\text {org }}$ values of sedimentary OM (Fig. 5).

However, with progressing eutrophication since $\mathrm{AD} 1870$ the $\delta^{13} \mathrm{C}_{\text {org }}$ values become more positive again (Fig. 5). Diatom-inferred TP $\left(20.8 \pm 1.9 \mu \mathrm{g} \mathrm{l}^{-1}\right)$ also reflects enhanced phosphorus input triggered by the massive deforestation related to the construction of the two mountain huts in AD 1866 (Müller, 1922). The limitation of carbon availability in the course of the rise in algae biomass results in decreasing isotopic discrimination during photosynthesis, culminating in more ${ }^{13} \mathrm{C}$-enriched $\mathrm{OM}$ (Fogel \& Cifuentes, 1993), and the rising flux of ${ }^{13} \mathrm{C}$ enriched phytoplankton biomass started to overprint the microbially influenced isotopic signals after $\sim \mathrm{AD}$ 1870 .

Plotting $\delta^{15} \mathrm{~N}$ versus $\delta^{13} \mathrm{C}_{\text {org }}$ (Fig. 6) reveals a combination of methane oxidation processes and incipient denitrification in the deeper part of the core (Findlay \& Kendall, 2007). We assume that denitrification processes in context with the enhanced allochthonous input due to the high precipitation rates may have stimulated the weak rise in $\delta^{15} \mathrm{~N}$ values. This trend was additionally promoted by livestock, deforestation, and, after 1866 , by the dry toilet, as human and animal waste is enriched in ${ }^{15} \mathrm{~N}$ (Kendall, 1998).

\section{Period II (AD 1880-AD 1980): rising temperatures, increasing eutrophication and atmospheric $N$ fertilisation}

Rising temperatures towards the end of the LIA led to increasing photosynthesis rates (Hall \& Smol, 2010) documented by rising diatom densities and pigment concentrations after $\sim$ AD 1880 (Figs. 3B, 4). Within the benthic diatom assemblages, some structural shifts occurred especially within the small fragilarioids (Fig. 3A). Staurosira microstriata, a taxon indicating low mean summer water temperatures (Schmidt et al., 2004), became absent after $\sim$ AD 1880. Pseudostaurosira elliptica a species favouring low $\mathrm{NO}_{3}$ concentrations (Morales, 2011) abruptly disappeared after $\sim$ AD 1960. The clear shift in the ratio between $S$. construens var. venter and S. pinnata around $\mathrm{AD}$ 
1970 may be indicative for gradually rising water temperatures, as $S$. construens var. venter was described as being more competitive under cooler conditions, while $S$. pinnata is more frequent during warmer periods (Cremer et al., 2001; Joynt \& Wolfe, 2001; Bouchard et al. 2004). However, in line with Spaulding et al. (2015), we rather suppose the combined effect of rising temperatures and increasing nitrogen loadings may have triggered changes within the diatom assemblages.

Low alloxanthin/diatoxanthin and high $\mathrm{B} / \mathrm{P}$ ratios indicate favourable light conditions for benthic production (Figs. 3B, 4). However, diatom-inferred lakelevel increased since $\sim \mathrm{AD} 1880$ inferred from decreasing frequency of epilithic species, such as $A$. minutissimum and D. tenuis. Hofmann et al. (2020) found that the distribution of the benthic diatoms in Oberer Soiernsee mainly depends on substrate availability. Epilithic species primarily occurred in the upper littoral zone $(0-7 \mathrm{~m})$, while epipsammic and epipelic diatom prefer the deeper littoral (7-11 m). We assume that the diatom-inferred lake-level changes are rather the consequence of enhanced availability of fine-grained substrate reflecting climate-mediated changes of the catchment. TOC/TN values revealed enhanced proportion of terrestrial sources on the sedimentary OM (Fig. 5). Between 1890 and the end of World War II, the small cabin situated at the northern shore of Oberer Soiernsee was rarely visited (Müller, 1922; cabin book; Alpine Yearbooks), as very well reflected by low diatom-inferred TP levels (mean $3.3 \pm 1.9 \mathrm{~g} \mathrm{l}^{-1}$ ). Diatom-inferred TP started to increase since $\sim$ AD 1950 (Fig. 3B). Concurrently declining $\delta^{13} \mathrm{C}_{\text {org }}$ indicates that respiration or, more likely, anoxic biochemical processes releasing ${ }^{13} \mathrm{C}$ depleted methane into the water column became increasingly important (Figs. 5, 6). The mesotrophic conditions around AD 1960 (diatom-inferred $\mathrm{TP}=27 \pm 1.9 \mu \mathrm{g}^{-1}$ ) may be due to the sharply increasing numbers of overnight stays in the small cabin since $\sim 1960$. Around the world the phosphorus loadings into water bodies markedly increased in the 1960s due to the development of phosphate detergents (Vollenweider, 1968). We suppose that the sharply rising TP is the result of the discharge of the cabin's wastewater.

The short-term increase in $\delta^{15} \mathrm{~N}$ (Fig. 5) may also be related to the rising numbers in overnight guests and day-trippers resulting in enhanced nitrate- $\mathrm{N}$ loadings from the nearby dry toilet, as human excrements are enriched in ${ }^{15} \mathrm{~N}$ (Kendall, 1998). A further positive correlation between $\delta^{15} \mathrm{~N}$ and $\delta^{13} \mathrm{C}_{\text {org }}$ would be expected if variations in these parameters continued to be caused mainly by alterations of the algae productivity (Gu et al., 1996; Finlay \& Kendall, 2007). However, the decoupling of both records after $\sim \mathrm{AD} 1970$ (Fig. 6) suggests the increasing influence of atmospheric nitrogen deposition from distant sources (fossil fuel combustion, industrial fertiliser and livestock) which is known to be a major external source of nitrogen in remote mountainous regions, especially since the 1950s (Catalan et al., 2013). Atmospheric nitrogen produced by agriculture and industry is ${ }^{15} \mathrm{~N}$ depleted relative to preindustrial sources (Hastings et al., 2009). The clear and continuous depletion in sedimentary $\delta^{15} \mathrm{~N}$ after $\sim \mathrm{AD} 1970$ (Fig. 5) likely reflects the increasing influence of atmospheric nitrogen loading, a trend that was widely observed in lake sediments of the Northern Hemisphere (Holtgrieve et al., 2011).

\section{Period III (AD 1980-AD 2010): rapid climate warming reinforced eutrophication}

This period is characterised by the dramatic increase in both diatom productivity and pigment concentrations indicating that climate warming sharply reinforced the eutrophication processes impacting Oberer Soiernsee. Algal responses were accelerated when lakes surpassed a climate-mediated ecological threshold associated with the establishment of a stronger thermal stratification (Smol et al., 2005).

Since 1980 a particularly pronounced warming ( $\sim 0.5^{\circ} \mathrm{C}$ per decade) has been observed in the European Alps (Gobiet et al., 2014). Also, at the Zugspitze, $30 \mathrm{~km}$ west of Oberer Soiernsee, a significant increase in annual mean temperatures was documented (data provided by DWD, Schneefernerhaus). In the sediments of Oberer Soiernsee a shift within the paleopigment composition around AD 1980 indicate the climate-induced stabilisation of the pelagic habitat. Violaxanthin, a proxy for cooler conditions (de Jong et al., 2013) suddenly disappeared and the indicators for a stronger thermal stabilisation (alloxanthin, peridinin and all green algae marker pigments) concurrently increased after $\sim \mathrm{AD} 1980$ (Fig. 4). 
However, besides the rising air temperatures, changes in light transmission and heat transfer may also have contributed to the stabilisation of the thermal stratification in Oberer Soiernsee. Climate-mediated changes in catchment vegetation cover, increased soil development and treeline migration (Vinebrooke and Leavitt, 1998; Sommaruga et al., 1999) may have led to an enhanced terrestrial input of light-aborting particles such as suspended inorganic and organic material and dissolved organic matter (DOC; Saros \& Anderson, 2014) resulting in a enhanced heat transfer to the lake.

Around AD 2000 the rapid increase in algal biomass (Figs. 3, 4) indicates that an ecological threshold related to post-1980 warming has been surpassed. The intertwined stresses of rising temperatures and longstanding nutrient inputs from mountain hut tourism, atmospheric nitrogen fertilisation and climate-related catchment changes culminate in a marked increase in paleopigment (up to 14-fold) and diatom (4-fold) concentrations. The success of labile pigments (fucoxanthin, neoxanthin, peridinin) and rising chl $a /$ phea ratios point to reduced pigment degradation, which is also indicative for enhanced primary productivity as light and oxygen availability was reduced and dead OM was buried more rapidly. Therefore, the favourable preservation conditions possibly overestimate the rapid increase in pigment concentrations. Furthermore, it should be noted that the concentrations of sedimentary pigments are generally much higher in the topmost sediment layers than in the deeper part of the sediment core, because the degradation processes are still in progress (Tõnno et al., 2019).

The marked negative shift (3.1\%o) towards significantly lower $\delta^{13} \mathrm{C}_{\mathrm{org}}$ values after $\sim \mathrm{AD} 1980$ (Fig. 5) indicates that enhanced lake productivity triggered methane oxidation processes. Additionally, methanogenesis and subsequent oxidation of the ${ }^{13} \mathrm{C}$-depleted methane could occur also under oxic conditions in freshwater lakes (Bogard et al., 2014; Thottathil et al., 2018). The increase in total algae biomass suggests a progressive oxygen depletion at the bottom of the lake since $\sim$ AD 1980, reinforced by the stronger thermal stability.

The continuously decreasing $\delta^{15} \mathrm{~N}$ values, however, did not reflect the denitrification processes. We assume that the continuous deposition of atmospheric nitrogen overrides the in-lake $\mathrm{N}$-isotope dynamics, a process also described by Lehmann et al. (2004). As atmospheric nitrogen deposition in Europe declined after the peak in 1980 (Engardt et al., 2017) a reversal trend in $\delta^{15} \mathrm{~N}$ towards more positive values could have been expected after $\sim \mathrm{AD}$ 1980. However, $\delta^{15} \mathrm{~N}$ continues to decline (Fig. 5). Continuous atmospheric measurements since 1995 revealed no negative trend in the concentrations of atmospheric nitrogen oxides at the northern foothills of the Alps (DWD, Hohenpeißenberg). Measuring nitrogen deposition in a twoyear monitoring of sites in the Northern Alps located $\sim 20 \mathrm{~km}$ west of Oberer Soiernsee, Kirchner et al. (2014) observed that the region is even nowadays affected by marked deposition rates of nitrogen due to long-range atmospheric transport.

The broken-stick model revealed no significant diatom assemblage changes between $\mathrm{AD} 1980$ and $\mathrm{AD}$ 2010. However, the ratio of benthic/epiphytic versus planktic frustules (B:P ratio) slightly decreased in this period (Fig. 3B), while the ratio between alloxanthin and diatoxanthin markedly increased and diatominferred lake levels reached a maximum (12.5 m; Fig. 4). We assume, that the diatom-inferred lakelevel rise is rather the consequence of reduced light penetration due to phytoplankton shading limiting the light availability for benthic diatom species.

\section{Period IV (AD 2010-AD 2017): rapid warming and an extreme precipitation event}

Rapid warming appeared to be the main driver for surpassing an important ecological threshold resulting in the recent success of planktic diatom species. In the Northern Alps the increase in air temperatures was again markedly accelerated around 2010 (data provided by DWD, Schneefernerhaus), resulting in significantly rising surface water temperatures (Dokulil, 2013), entailing a shorter ice-cover duration (Thompson et al., 2005; Weckström et al., 2014), longer growing seasons (Smol, 1988), the alteration of the balance between thermal stratification and turbulent mixing (Luoto \& Nevalainen, 2013; Butcher et al., 2015), the development of more diverse littoral habitats (Lotter et al., 2010), and changes regarding the availability of light and nutrient resources (Douglas \& Smol, 2010).

The stabilisation of the pelagic habitat and the establishment of macrophytes as substrate for epiphytic taxa (e.g. Encyonopsis spp.) appeared to represent a tipping point in the ecosystem of lake 
Oberer Soiernsee indicated by a marked shift towards more complex, species rich diatom assemblages and distinctly rising abundances of planktic species (Fig. 3A, B). Especially small Cyclotella/Pantocsekiella species and $F$. nanana occurred more frequently after $\sim \mathrm{AD} 2010$ and their abundances abruptly increased after $\sim$ AD 2015. Diatom-inferred temperature reconstructions by using the novel silicification value (Kuefner et al., 2020a, b) revealed an abrupt warming of lake surface temperatures after AD 2015 (Fig. 3B). However, the direct effect of rising air temperatures is not likely alone the driver of diatom species shifts. Stratification patterns and mixing regimes were also regulated by the amount of light adsorbing particles. The marked increase in phytoplankton biomass and the extremely large amount of inorganic particles and soils released from the catchment after the extreme precipitation event in August 2015 reinforced the heat transfer into the lake by the enhanced adsorption of light energy. The complex interactions between the mechanism controlling the stratification patterns and the resulting effect of changing thermal regimes on the availability of light and nutrients greatly influence growth, structure and competition of both planktic and periphytic algae communities (Winder \& Sommer, 2012; Saros \& Anderson, 2014; Malik et al., 2017).

Sharply declining B:P ratios and increasing diatominferred lake levels after $\sim$ AD 2015 (Fig. 3B) indicated favourable conditions for planktic diatoms. Cyclotella/Pantocsekiella spp. and $F$. nanana have competitive advantages during times of stronger stratification due to their low sinking rates, excellent light-harvesting skills and efficient nutrient uptake (small centrics) and their ability to reduce sinking velocity by forming ribbon-like colonies ( $F$. nanana). Numerous diatom paleo-records from sites across a wide geographic range highlighted the recent success of small, fast-growing cyclotelloid species with enhanced water column stability and reduced vertical mixing (e.g. Rühland et al., 2003, 2008, 2015; Douglas et al., 2004; Rühland and Smol, 2005; Karst-Riddoch et al., 2005; Smol et al., 2005; Kuefner \& Hofmann et al., 2020). However, changes in nutrient concentrations also may have triggered shifts in the abundances of Cyclotella/Pantocsekiella spp., as this species prefer oligo- to moderately mesotrophic waters. Pantocsekiella comensis, a taxon that is known to be a characteristic species in oligotrophic lakes
(Marchetto \& Bettinetti, 1995, Marchetto et al., 2004; Reynolds, 2006; Werner \& Smol, 2006; Berthon et al., 2014; Saros \& Anderson, 2014) occurred in low abundances (0.5-0.6\%) between AD 1880 and AD 1900, reappeared around $\mathrm{AD} 2015(1 \%)$ and subsequently sharply increased up to $30 \%$. Contemporary hydrochemical analyses revealed decreasing TP concentrations from 14.4 to $4.5 \mu \mathrm{g} \mathrm{l}^{-1}$ and increasing nitrate-N concentrations from 0.27 to $0.36 \mathrm{mg} \mathrm{l}^{-1}$ after the extreme precipitation event in August 2015 (Hofmann et al., 2020; Ossyssek et al., 2020). Analysing the distribution of $P$. comensis across oligotrophic mountain lakes in the northern European Alps, Ossyssek et al. (2020) additionally found that this taxon was positively correlated with the nitrate- $\mathrm{N}$ concentrations providing an indicator for rising water temperatures under elevated nitrate concentrations. Beside atmospheric fertilisation, catchment soils are the main external nitrogen resource in remote lakes (Saros \& Anderson, 2014). Based on the TOC/TN ratios and the fingerprints of modern OM sources terrestrial soils were found to influence the composition of the sedimentary OM deposited after AD 2015 (Fig. 6). Rising TOC/TN ratios after AD 2015 also suggest enhanced autochthonous sources of sedimentary $\mathrm{OM}$ (Fig. 5).

The marked collapse of the diatom cell densities and pigment concentrations (Figs. 3, 4) is related to the extensive catchment denudation triggered by the massive thunderstorm in August 2015. Highly turbid conditions existed for several weeks (Hofmann et al., 2020) and a 4-5 cm thick flood layer was deposited. During the cold period of LIA an increased frequency of flood events been observed (Fig. 1). The recent global warming, however, was found to increase the intensity of heavy rainfall events resulting in a significantly increasing activity of landslides and debris flows in the Northern Calcareous Alps (Dietrich \& Krautblatter, 2016).

The AD 2015 flood event resulted in the reversal of the declining $\delta{ }^{13} \mathrm{C}_{\mathrm{org}}$ trend. We presume that the flood layer sealed the lake bottom and inhibited the resolution of TP. Contemporary hydrochemical analyses revealed steadily decreasing TP concentrations from $14.4 \mu \mathrm{g} \mathrm{l}^{-1}$ (2015) to $11.8 \mu \mathrm{g} \mathrm{l}^{-1}$ (2016) to $4.5 \mu \mathrm{g}^{-1}$ (2017). Diatom-inferred TP concentrations show a similar trend from $8.4 \pm 1.9 \mu \mathrm{g} \mathrm{l}^{-1}$ (2015) to $4.5 \pm 1.9 \mu \mathrm{g}^{-1}$ (2017). Further investigations are needed to determine whether this is only a short-term 
phenomenon or whether the flood layer has the potential for a long-term influence over the lake's nutrient state.

\section{Conclusions}

The results of our study show that lake responses to climatic and human influences are complex, multidimensional, and often indirectly mediated through watershed processes.

The sedimentological, biological and biogeochemical information stored in its sediments revealed the eutrophication history of Oberer Soiernsee since the end of the Little Ice Age (AD 1840-AD 2017). By combining the multiple proxies, we were able to disentangle external disturbances and lake-internal processes and to unravel the complex responses of lake algae to local human activities, long-distance atmospheric deposition and climate warming.

We could demonstrate that changes in catchmentlake interaction linked to climate warming are mirrored in the sediment archives, in particular by changes in the frequency and intensity of extreme rainfall events and in the release of nutrients and DOC into the lake.

Our findings confirm the benefit of combined analyses of $\delta^{13} \mathrm{C}_{\text {org }}$ and $\delta^{15} \mathrm{~N}$ values as well as TOC and $\mathrm{TN}$ contents of sedimentary $\mathrm{OM}$ to reveal and explain changing trophic conditions. Comparing with isotopic values of modern $\mathrm{OM}$, we were able to determine the origin of sedimentary OM as mainly autochthonous (algae), partly influenced by terrestrial soils. Diatom productivity and species composition and the concentrations of chlorophyll $a$ and $\beta$-carotene were found to share the analytical capability to reconstruct lake eutrophication.

Anthropogenic climate change and the linked chain of causal factors were found to be the main drivers influencing algal dynamics and species composition. The diatom record provided an important tool to reveal climate warming signals and alterations regarding water column transparency, TP- and nitrate-N concentrations. The timing of the establishment of thermal stratification could be determined via the success of centric diatoms and via the marker pigments of Dinophyta and Cryptophyta.

Our study highlights the threat multiplier character of climate change on mountain lakes influenced by local human activities, resulting in amplified responses of algal communities. Based on the findings of this study, we assume that climatically induced ecological thresholds have already been surpassed in most of the Alpine lakes. In view of the present and future challenges in effectively managing water resources our findings underline the urgency of a sharp reduction of local and atmospheric nutrient input to maintain valuable ecosystem services under future climate scenarios.

Acknowledgements We are grateful to Tanja Gschlößl for her appreciative feedback. We thank Steve Juggings for providing the TP dataset from EDDI. Special thanks are due to Stefan Ossyssek for supporting TP and lake-level reconstructions in R. We are thankful to Stefan Ossyssek and Franziska Bauer for support in the field and to Nadja Schlieder for assistance in the isotope laboratory.

Author contributions AMH: Writing-original draft, Conceptualisation, Analysis and Investigation, Methodology, Data curation, Validation. WK: Methodology, Writing-review and editing. ND: Methodology, Writing - review and editing. CM: Methodology, Writing-review and editing. JG: Supervision, Validation, Writing-review and editing. UR: Funding acquisition, Project administration, Supervision, Validation; Writing—review and editing.

Funding Open Access funding enabled and organized by Projekt DEAL. This study was funded by the Bavarian State Ministry of the Environment and Consumer Protection within the Project "Impact of Climate Change on Bavarian mountain lakes" (Grant number TKP01KPB-70807).

Data availability The authors will make the data available on request.

\section{Declarations}

Conflict of interest The authors declare that they have no competing financial interest or personal relationships that could have influenced the work reported in this manuscript.

Open Access This article is licensed under a Creative Commons Attribution 4.0 International License, which permits use, sharing, adaptation, distribution and reproduction in any medium or format, as long as you give appropriate credit to the original author(s) and the source, provide a link to the Creative Commons licence, and indicate if changes were made. The images or other third party material in this article are included in the article's Creative Commons licence, unless indicated otherwise in a credit line to the material. If material is not included in the article's Creative Commons licence and your intended use is not permitted by statutory regulation or exceeds the permitted use, you will need to obtain permission directly from the copyright holder. To view a copy of this licence, visit http://creativecommons.org/licenses/by/4.0/. 


\section{References}

Appleby, P. G., 2001. Chronostratigraphic techniques in recent sediments. In Last, W. M. \& J. P. Smol (eds), Tracking Environmental Change Using Lake Sediments. Kluwer Academic Publisher, Dordrecht: 171-203.

Barker, P., J. C. Fontes, F. Gasse \& J.-C. Druart, 1994. Experimental dissolution of diatom silica in concentrated salt solutions and implications for paleoenvironmental reconstruction. Limnology and Oceanography 39: 99-110.

Bätzing, W., 2015. Die Alpen Geschichte und Zukunft einer europäischen Kulturlandschaft. C.H. Beck Verlag, Munich.

Beniston, M., 2006. Mountain weather and climate: a general overview and a focus on climatic change in the Alps. Hydrobiologia 562: 3-16.

Bennet, K. D., 1996. Determination of the number of zones in a biostratigraphical sequence. New Phytologist 132: 155-170.

Berthon, V., B. Alric, F. Rimet \& M.-E. Perga, 2014. Sensitivity and responses of diatoms to climate warming in lakes heavily influenced by humans. Freshwater Biology 59: 1755-1767.

Birks, H. H. \& H. J. B. Birks, 2006. Multi-proxy studies in paleolimnology. Vegetation History and Archaeobotany 15: $235-251$.

Boeff, K. A., K. E. Strock \& J. E. Saros, 2016. Evaluating planktonic diatom response to climate change across three lakes with differing morphometry. Journal of Paleolimnology 56: 33-47.

Bogard, M. J., P. A. del Giorgio, L. Boutet, M. C. Garcia Chaves, Y. T. Prairie, A. Merante \& A. M. Derry, 2014. Oxic water column methanogenesis as a major component of aquatic $\mathrm{CH}_{4}$ fluxes. Nature Communication 5: 5350.

Bogataj, L. K., 2007. How will the Alps respond to climate change? Scenarios for the future of Alpine water. Alpine Space: Man and Environment 3: 43-51.

Bouchard, G., K. Gajewski \& P. B. Hamilton, 2004. Freshwater diatom biogeography in the Canadian Arctic Archipelago. Journal of Biogeography 31: 1955-1973.

Bracht-Flyr, B. \& S. C. Fritz, 2016. Combining lake core records with the limnologic model DYRESM-CAEDYM to evaluate lake response during the Little Ice Age and Medieval Climate Anomaly. Journal of Paleolimnology 56: 79-92.

Braig E., C. Mayr, G. Kirchner, A. Hofmann, U. Raeder \& A. Melzer, 2013. Fifty years of eutrophication and lake restoration reflected in sedimentary carbon and nitrogen isotopes of a small, hardwater lake (South Germany). Journal of Limnology 72: 262-279.

Brand, W. A., T. B. Coplen, J. Vogl, M. Rosner \& T. Prohaska, 2014. Assessment of international reference materials for isotope-ratio analysis (IUPAC Technical Report). IUPA Technical Report. Pure and Applied Chemistry 86: 425-467.

Buchaca, T. \& J. Catalan, 2007. Factors influencing the variability of pigments in the surface sediments of mountain lakes. Freshwater Biology 52: 1365-1379.

Buchaca, T. \& J. Catalan, 2008. On the contribution of phytoplankton and benthic biofilms to the sediment record of marker pigments in high mountain lakes. Journal of Paleolimnology 40: 369-383.

Butcher, J. B., D. Nover, T. E. Johnson \& C. M. Clark, 2015. Sensitivity of lake thermal and mixing dynamics to climate change. Climate Change 129: 295-305.

Catalan, J., S. Pla-Rabes, A. P. Wolfe, J. P. Smol, K. M. Rühland, N. J. Anderson, J. Kopácek, E. Stuchlík, R. Schmidt, K. A. Koinig, L. Camarero, R. Flower, O. Heiri, C. Kamenik, A. Korhola, P. R. Laevitt, R. Psenner \& I. Renberg, 2013. Global change revealed by palaeolimnological records from remote lakes: a review. Journal of Paleolimnology 49: 513-535.

Cremer, H., M. Melles \& B. Wagner, 2001. Holocene climate changes reflected in a diatom succession from Basalts $\emptyset$, East Greenland. Canadian Journal of Botany 79: 649-656.

De Jong, R., C. Kamenik, K. Westover \& M. Grosjean, 2013. A chrysophyte stomatocyst-based reconstruction of coldseason air temperature from Alpine Lake Silvaplana (AD 1500-2003); methods and concepts for quantitative inferences. Journal of Paleolimnology 50: 519-533.

DeNiro, M. J. \& S. Epstein, 1981. Influence of diet on the distribution of nitrogen isotopes in animals. Geochimica et Cosmochimica Acta 42: 495-506.

Dietrich, A. \& M. Krautblatter, 2016. Evidence for enhanced debris-flow activity in the Northern Calcareous Alps since the 1980s (Plansee, Austria). Geomorphology 287: 144-158.

DIN EN 13946:2014-07: Water Quality - Guidance for the Routine Sampling and Preparation of Benthic Diatoms from Rivers and Lakes; German Version EN 13946:201.

Dokulil, M. T., 2013. Impact of climate warming on European inland waters. Inland Waters 4: 27-40.

Douglas, M. S. V. \& J. P. Smol, 2010. Freshwater diatoms as indicators of environmental change in the High Arctic. In Stoermer, E. F. \& J. P. Smol (eds), The Diatoms: Applications for the Environmental and Earth Sciences. Cambridge University Press, Cambridge: 249-266.

Douglas, M. S. V., P. B. Hamilton \& R. Pienitz, 2004. Algal indicators of environmental change in Arctic and Antarctic lakes and ponds. In Pienitz, R., M. S. V. Douglas \& J. P. Smol (eds), 2004. Long-Term Environmental Change in Arctic and Antarctic Lakes. Kluwer Academic Publishers, Dordrecht: 117-147.

DWD (Deutscher Wetterdienst). Schneefernerhaus: Meteorological Data [available on internet at https:// schneefernerhaus.de/daten/monatsrueckblicke/archiv/]. Accessed 20 Jan 2021.

DWD (Deutscher Wetterdienst). Hohenpeißenberg: Time Series of Nitrogen Oxide Concentrations [available on internet at https://www.dwd.de/DE/forschung/atmosphaerenbeob/ zusammensetzung_atmosphaere/spurengase/inh_nav/nox. html?nn=19216]. Accessed 20 Jan 2021.

Engardt, M., D. Simpson, M. Schwikowski \& L. Granat, 2017. Deposition of sulphur and nitrogen in Europe 1900-2050. Model calculations and comparison to historical observations. Tellus B: Chemical and Physical Meteorology, 69: 1.

Farquhar, G. D., J. R. Ehleringer \& K. T. Hubick, 1989. Carbon isotope discrimination and photosynthesis. Annual Review of Plant Physiology 40: 503-537.

Finlay, J. C. \& C. Kendall, 2007. Stable isotope tracing of temporal and spatial variability in organic matter sources to 
freshwater ecosystems. In Michener, R. \& K. Lajtha (eds), Stable Isotopes in Ecology and Environmental Science. Blackwell, Oxford: 283-333.

Fogel, M. L. \& L. A. Cifuentes, 1993. Isotope fractionation during primary production. In Engel, M. H. \& S. A. Macko (eds), Organic Geochemistry. Plenum Press, New York: 73-98.

Fritz, S. C., 2008. Deciphering climatic history from lake sediments. Journal of Paleolimnology 39: 5-16.

Giguet-Covex, C., F. Arnaud, D. Enters, J. Poulenard, L. Millet, P. Francus, F. David, P.-J. Rey, B. Wilhelm \& J.-J. Delannoy, 2012. Frequency and intensity of high-altitude floods over the last $3.5 \mathrm{ka}$ in northwestern French Alps (Lake Anterne). Quaternary Research 77: 12-22.

Gobiet, A., S. Kotlarski, M. Beniston, G. Heinrich, J. Rajczak \& M. Stoffel, 2014. 21st century climate change in the European Alps - a review. Science of the Total Environment 493: 1138-1151.

Griffiths, K., N. Michelutti, M. Sugar, M. S. V. Douglas \& J. P. Smol, 2017. Ice-cover is the principal driver of ecological change in High Arctic lakes and ponds. PLoS ONE 12(3): e0172989.

$\mathrm{Gu}, \mathrm{B} ., 2009$. Variations and controls of nitrogen stable isotopes in particulate organic matter of lakes. Oecologia 160: 421-431.

Gu, B., C. L. Schelske \& M. Brenner, 1996. Relationship between sediment and plankton isotope ratios $\left(\delta^{13} \mathrm{C}\right.$ and $\delta^{15} \mathrm{~N}$ ) and primary productivity in Florida lakes. Canadian Journal of Fisheries and Aquatic Science 53: 875-883.

Hall, R. I. \& J. P. Smol, 2010. Diatoms as indicators of lake eutrophication. In Stoermer E. F. \& J. P. Smol (eds), The Diatoms: Applications for the Environmental and Earth Sciences. Cambridge University Press, Cambridge: $122-151$.

Hammer, Ø. \& D. A. T. Harper, 2006. Paleontological Data Analysis. Blackwell, Malden.

Hastings M. G., J. C. Jarvis \& E. J. Steig, 2009. Anthropogenic Impacts on nitrogen isotopes of ice-core nitrate. Science 324: 1288.

Hofmann, A. M., J. Geist, L. Nowotny \& U. Raeder, 2020. Depth-distribution of lake benthic diatom assemblages in relation to light availability and substrate: implications for paleolimnological studies. Journal of Paleolimnology 64: 315-334.

Hofmann, G., M. Werum \& H. Lange-Bertalot, 2013. Diatomeen im Süßwasser-Benthos von Mitteleuropa. 2. Auflage. Koeltz Scientific Books, Königstein.

Hollander, D. J. \& M. A. Smith, 2001. Microbially mediated carbon cycling as a control on the $\delta^{13} \mathrm{C}$ of sedimentary carbon in eutrophic Lake Mendota (USA): new models for interpreting isotopic excursions in the sedimentary record. Geochimica et Cosmochimica Acta 65: 4321-4337.

Holtgrieve, G. W., D. E. Schindler, W. O. Hobbs, P. R. Leavitt, E. J. Ward, L. Bunting, G. Chen, B. P. Finney, I. GregoryEaves, S. Holmgren, M. J. Lisac, P. J. Lisi, K. Nydick, L. A. Rogers, J. E. Saros, D. T. Selbie, M. D. Shapley, P. B. Walsh \& A. P. Wolfe, 2011. A coherent signature of anthropogenic nitrogen deposition to watersheds of the Northern Hemisphere. Science 334: 1545-1548

Houk, V., R. Klee \& H. Tanaka, 2010. Atlas of Freshwater Centric Diatoms with a Brief Key and Descriptions. Part
III. Stephanodiscaceae A. Cyclotella, Tertiarius, Discostella Fottea. Czech Phycological Society, Praha.

Houk, V., R. Klee \& H. Tanaka H, 2014. Atlas of Freshwater Centric Diatoms with a Brief Key and Descriptions. Part IV. Stephanodiscaceae B. Stephanodisus, Cyclostephanus, Pliocaenicus, Hemistephanos, Stephanocistis, Mesodictyon, Spicaticribia Fottea. Czech Phycological Society, Praha.

Ilyashuk, E. A., O. Heiri, B. P. Ilyashuk, K. A. Koinig \& R. Psenner, 2018. The Little Ice Age signature in a 700-year high-resolution chironomid record of summer temperatures in the Central Eastern Alps. Climate Dynamics 52: 6953-6967.

IPCC, 2013. Summary for policymakers. In Stocker, T. F., D. Qin, G.-K. Plattner, M. Tignor, S. K. Allen, J. Boschung, A. Nauels, Y. Xia, V. Bex \& P. M. Midgley (eds), Climate Change. The Physical Science Basis. Contribution of Working Group I to the Fifth Assessment Report of the Intergovernmental Panel on Climate Change. IPCC, Cambridge.

Jeppesen, E., B. Moss, H. Bennion, L. Carvalho, L. DeMeester, H. Feuchtmayr, N. Friberg, M. O. Gessner, M. Hefting, T. L. Lauridsen, L. Liboriussen, H. J. Malmquist, L. May, M. Meerhoff, J. S. Olafsson, M. B. Soons \& J. T. A. Verhoeven, 2010. Interaction of climate change and eutrophication. In Kernan, M., R. Battarbee \& B. Moss (eds), Climate Change Impacts on Freshwater Ecosystems. Blackwell Publishing Ltd., Berlin.

Joynt, E. H. III \& A. P. Wolfe, 2001. Paleoenvironmental inference models from sediment diatom assemblages in Baffin Island lakes (Nunavut, Canada) and reconstruction of summer water temperature. Canadian Journal of Fisheries and Aquatic Science 58: 1222-1243.

Juggins, S., 2007. C2 User Guide. Software for Ecological and Paleoecological Data Analysis and Visualisation. University of Newcastle, Newcastle upon Tyne.

Juggins, S., 2013. Quantitative reconstructions in paleolimnology: a new paradigm or sick science? Quaternary Science Reviews 64: 20-32.

Juggins, S., 2018. Package 'rioja'. CRAN R-Project, 1-58.

Karst-Riddoch, T. L., M. F. J. Pisaric \& J. P. Smol, 2005. Diatom responses to 20th century climate-related environmental changes in high-elevation mountain lakes of the northern Canadian Cordillera. Journal of Paleolimnology 33: 265-282.

Kendall, C., 1998. Tracing nitrogen sources and cycling in catchments. In Kendall, C., \& J. J. McDonnell (eds), Isotope Tracers in Catchment Hydrology. Elsevier Science, Amsterdam: 519-576.

Kirchner, G., 2011. ${ }^{210} \mathrm{~Pb}$ as a tool for establishing sediment chronologies: examples of potentials and limitations of conventional dating models. Journal of Environmental Radioactivity 102: 490-494.

Kirchner, M., W. Fegg, H. Römmelt, M. Leuchner, L. Ries, R. Zimmermann, B. Michalke, M. Wallasch, J. Maguhn, T. Faus-Kessler \& G. Jakobi, 2014. Nitrogen deposition along differently exposed slopes in the Bavarian Alps. Science of the Total Environment 470-471: 895-906.

Körner, C., W. Jetz, J. Paulsen, D. Payne, K. Rudmann-Maurer \& E. M. Spehn, 2016. A global inventory of mountains for bio-geographical applications. Alpine Botany 127: 1-15. 
Krammer, K., 1997. Die cymbelloiden Diatomeen. Eine Monographie der weltweit bekannten Taxa, 1-2. Bibliotheca Diatomologica. Cramer, Berlin.

Krammer, K. \& H. Lange-Bertalot, 1986-1991. Bacillariophyciae 1-4. In Ettl, H., J. Gerloff, H. Heynig \& D. Mollenhauer (eds), Süßwasserflora von Mitteleuropa. Gustav Fischer Verlag, Stuttgart.

Kuefner, W., A. M. Hofmann, S. Ossyssek, N. Dubois, J. Geist J \& U. Raeder, 2020. Composition of highly diverse diatom community shifts as response to climate change: a downcore study of 23 central European mountain lakes. Ecological Indicators 117: 106590.

Kuefner, W., A. M. Hofmann, J. Geist \& U. Raeder, 2020a. Evaluating climate change impacts on mountain lakes by applying the new silicification value to paleolimnological samples. Science of the Total Environment 715: 136913.

Kuefner, W., S. Ossyssek, J. Geist \& U. Raeder, 2020b. The silicification value: a novel diatom-based indicator to assess climate change in freshwater habitats. Diatom Research 35(1): 1-16.

Lami, A., P. Guilizzoni \& A. Marchetto, 2000. High resolution analysis of fossil pigments, carbon, nitrogen and sulfur in the sediment of eight European Alpine lakes: the MOLAR project. Journal of Limnology 59: 15-28.

Lange-Bertalot, H., 1993. 85 Neue Taxa und über 100 weitere neu definierte Taxa ergänzend zur Süßwasserflora von Mitteleuropa. Vol. 2. Bibliotheca Diatomologica 27, J. Cramer, Berlin.

Lange-Bertalot, H. \& K. Krammer, 2000-2003. Diatoms of Europe Vol. 1-4, A.R.G. Ganter Verlag K.G., Rugell.

Lange-Bertalot, H., K. Külbs, T. Lauser, M. Nörpel-Schempp \& M. Willmann, 1996. Annotated Diatom Monographs. Iconographia Diatomologica 3. Koeltz Scientific Books, Königstein.

Lauber, U. \& N. Goldscheider, 2014. Use of artificial and natural tracers to assess groundwater transit-time distribution and flow systems in a high-alpine karst system (Wetterstein Mountains, Germany). Hydrogeology Journal 22: 1807-1824.

Leavitt, P. R., 1993. A review of factors that regulate carotenoid and chlorophyll deposition and fossil pigment abundance. Journal of Paleolimnology 9: 109-127.

Leavitt, P. R. \& D. A. Hodgson, 2001. Sedimentary pigments. In Smol. J. P., H. J. B. Birks \& W. M. Last (eds), Tracking Environmental Change Using Lake Sediments. Terrestrial, Algal and Siliceous Indicators, Vol. 3. Kluwer Academic Publishers, Dordrecht.

Legendre, P. \& E. D. Gallagher, 2001: Ecologically meaningful transformations for ordination of species data. Oecologia 129: 271-280.

Lehmann, M. F., S. M. Bernasconi, J. A. McKenzie, A. Barbieri, M. Simona \& M. Veronesi, 2004. Seasonal variation of the $\delta^{13} \mathrm{C}$ and $\delta^{15} \mathrm{~N}$ of particulate and dissolved carbon and nitrogen in Lake Lugano: constraints on biogeochemical cycling in a eutrophic lake. Limnology and Oceanography 49: 415-429.

Lewin, J. C., 1961. The dissolution of silica from diatom walls. Geochimica et Cosmochimica Acta 21: 182-198.

Lotter, A. F., J. B. Birks, W. Hofmann \& A. Marchetto, 1998. Modern diatom, cladocera, chironomid, and chrysophyte cyst assemblages as quantitative indicators for reconstruction of past environmental changes in the Alps. II. Nutrients. Journal of Paleolimnology 19: 443-463.

Lotter, A. F. \& C. Bigler, 2000. Do diatoms in the Swizz Alps reflect the length of ice cover? Aquatic Sciences 62: 125-141.

Lotter, A. F., R. Pienitz \& R. Schmidt, 2010. Diatoms as indicators of environmental change in Arctic and Alpine regions. In Stoermer E. F. \& J. P. Smol (eds), The Diatoms. Applications for the Environmental and Earth Sciences. Cambridge University Press, Cambridge: 231-248.

Luoto, T. P. \& L. Nevalainen, 2013. Long-term water temperature reconstructions from mountain lakes with different catchment and morphometric features. Scientific Reports 3: 2488

Magnuson, J. J., D. M. Robertson, B. J. Benson, R. H. Wynne, D. M. Livingstone, T. Arai, R. A. Assel, R. G. Barry, V. Card, E. Kuusisto, N. G. Granin, T. D. Prowse, K. M. Stewart \& V.S. Vuglinski, 2000. Historical trends in lake and river ice cover in the Northern Hemisphere. Science 289: 1743-1746.

Malik, H. I., R. M. Northington \& J. E. Saros, 2017. Nutrient limitation status of Arctic lakes affects the responses of Cyclotella sensu lato diatom species to light: implications for distribution patterns. Polar Biology 40: 2445-2456.

Mann, M. E., 2002a. The Little Ice Age. In MacCracken M. C. \& J. S. Perry (eds), Encyclopedia of Global Environmental Change. The Earth System: Physical and Chemical Dimensions of Global Environmental Change, Vol. 1. Wiley, Chichester: 504-509.

Mann, M. E., 2002b. The value of multiple proxies. Science 297:1481-1482

März, C., 1903. Der Seenkessel der Soiern - Ein Karwendelkar. Duncker und Humblot, Leipzig.

Marchetto, A. \& R. Bettinetti, 1995. Reconstruction of the phosphorus history of two deep, subalpine Italian lakes from sedimentary diatoms, compared with long-term chemical measurements. Mem. Ist. Ital. Idorbiol. 53: 27-38.

Marchetto, A., A. Lami, S. Musazzi, J. Massaferro, L. Langone \& P. Guilizzoni, 2004. Lake Maggiore (N. Italy) trophic history: fossil diatom, plant, pigment, and chironomids, and comparison with long-term limnological data. Quaternary International 113: 97-110.

Mayr, C., B. Brandlmeier, V. Diersche, P. Stojakowits, U. Kirscher, R. Matzke-Karasz, V. Bachtadse, M. Eigler, U. Haas, B. Lempe, P. J. Reimer \& C. Spötl, 2017. Nesselgraben, a new reference section of the last glacial period in southern Germany. Journal of Paleolimnology 58: 213-229.

McCarroll, D. \& N. J. Loader, 2004. Stable isotopes in tree rings. Quaternary Science Reviews 23: 771-801.

McKenzie, J. A., 1985. Carbon isotopes and productivity in the lacustrine and marine environment. In Stumm, W. (ed) Chemical Processes in Lakes. Wiley, New York: 99-118.

McMaster, N. L. \& D. W. Schindler, 2005. Planktonic and epipelic algal communities and their relationship to physical and chemical variables in alpine ponds in Banff National Park, Canada. Arctic, Antarctic, and Alpine Research 37: 337-347.

Meyers, P. A. \& J. L. Teranes, 2001. Sediment organic matter. In Last, W. M. \& J. P. Smol (eds), Tracking Environmental 
Change Using Lake Sediments. Physical und Geochemical Methods, Vol. 2. Kluwer Academic Publishers, Dordrecht.

Michelutti, N., C. A. Cooke, W. O. Hobbs \& J. P. Smol, 2015. Climate driven changes in lakes from the Peruvian Andes. Journal of Paleolimnology 54: 153-160.

Morales, E., 2011. Pseudostauroseira elliptica. In Diatoms of North America [available on internet at https://diatoms. org/species/pseudostaurosira_elliptica]. Accessed 24 Jan 2021.

Müller, E. M., 1922. Die Soiernhäuser. In Yearbook of the Alpine Club Section 1922: 105-110.

O'Reilly, C. M., S. Sharma, D. K. Gray, S. E. Hampton, et al., 2015. Rapid and highly variable warming of lake surface waters around the globe. Geophysical Research Letters 42: 10773-10781.

Ossyssek, S., J. Geist, P. Werner \& U. Raeder, 2020. Identification of the ecological preferences of Cyclotella comensis in mountain lakes of the northern European Alps. Arctic, Antarctic, and Alpine Research 52: 512-523.

Reynolds, C. S., 2006. The Ecology of Phytoplankton. Cambridge University Press, New York.

Rogora M., L. Frate, M. L. Carranza, M. Freppaz, A. Stanisci, I. Bertani, R. Bottarin, A. Brambilla, R. Canullo, M. Carbognani, C. Cerrato, S. Chelli, E. Cremonese, M. Cutini, M. Di Musciano, B. Erschbamer, D. Godone, M. Iocchi, M. Isabellon, A. Magnani, L. Mazzola, U. Morra di Cella, H. Pauli, M. Petey, B. Petriccione, F. Porro, R. Psenner, G. Rossetti, A. Scotti, R. Sommaruga, U. Tapperiner, J.-P. Theurillat, M. Tomaselli, D. Viglietti, R. Viterbi, P. Vittoz, M. Winkler \& G. Matteucci, 2018. Assessment of climate change effects on mountain ecosystems through a crosssite analysis in the Alps and Apennines. Science of the Total Environment 624: 1429-1442.

Rosbakh, S., M. Bernhardt-Roemermann \& P. Poschlod, 2014. Elevation matters: contrasting effects of climate change on the vegetation development at different elevations in the Bavarian Alps. Alpine Botany 124: 143-154.

Rühland, K., A. Priesnitz \& J.P. Smol, 2003. Paleolimnological Evidence from diatoms for recent environmental changes in 50 lakes across Canadian Arctic Treeline. Arctic, Antarctic, and Alpine Research 35: 110-123.

Rühland, K. \& J. P. Smol, 2005. Diatom shifts as evidence for recent Subarctic warming in a remote tundra lake, NWT, Canada. Palaeogeography, Palaeoclimatology, Palaeoecology 226: 1-16.

Rühland, K., A. M. Paterson \& J. P. Smol, 2008. Hemisphericscale patterns of climate-related shifts in planktonic diatoms from North American and European lakes. Global Change Biology 14: 2740-2754.

Rühland, K., A. M. Paterson \& J. P. Smol, 2015. Lake diatoms responses to warming: reviewing the evidence. Journal of Paleolimnology 54: 1-35.

Rühland, K., K. Rentz, A. M. Paterson, J. T. Teller \& J. P. Smol, 2018. The post-glacial history of northern Lake of the Woods: a multi-proxy perspective on climate variability and lake ontogeny. Journal of Great Lakes Research 44: 367-376.

Sanger, J. E., 1988. Fossil pigments in paleoecology and paleolimnology. Palaeogeography, Palaeoclimatology, Palaeoecology 62: 343-359.
Saros, J. E. \& N. J. Anderson, 2014. The ecology of the planktonic diatom Cyclotella and its implications for global environmental change studies. Biological Reviews 90: 522-541.

Schmidt, R., H. Lange-Bertalot \& R. Klee, 2004. Staurosira parasitoides sp. nova and Staurosira microstriata (Marciniak) Lange-Bertalot from surface sediment samples of Austrian alpine lakes. Algological Studies 114: 1-9.

Schmidt-Thomé, P., 1953. Beobachtungen an Karen im Vorkarwendel. Geologica Bavarica. Bayerisches Geologisches Landesamt, München.

Schwoerbel, J. \& H. Brendelberger (2013). Einführung in die Limnologie. Eutrophierung der Gewässer. Springer, Heidelberg: 249-252.

Smol, J. P., 1988. Paleoclimate proxy data from freshwater Arctic diatoms. SIL Proceedings 1922-2010 23(2): 837-844.

Smol, J. P., 2008. Pollution of Lakes and Rivers: A Paleoenvironmental Perspective, 2nd edn. Blackwell Publishing, Oxford.

Smol, J. P., 2010. The power of the past: using sediments to track the effects of multiple stressors on lake ecosystems. Freshwater Biology 55: 43-59.

Smol, J. P \& B. F. Cumming, 2000. Tracking long-term changes in climate using algal indicators in lake sediments. Journal of Phycology 36: 986-1011.

Smol, J. P., A. P. Wolfe, H. J. B. Birks, M. S. V. Douglas, V. J. Jones, A. Korhola, R. Pienitz, K. Rühland, S. Sorvari, D. Antoniades, S. J. Brooks, M.-E. Fallu, M. Hughes, B. E. Keatley, T. R. Laing, N. Michelutti, M. Nyman, A. M. Paterson, B. Perren, R. Quinlan, M. Rautio, E. SaulnierTalbot, S. Siitonen, N. Solovieva \& J. Weckström, 2005. Climate-driven regime shifts in the biological communities of Arctic lakes. Proceedings of the National Academy of Sciences of USA 102: 4397-4402.

Sommaruga, R., R. Psenner, E. Schaffner, K. Koinig, S. Sommaruga-Wögrath, 1999. Dissolved organic carbon concentration and phytoplankton biomass in high-mountain lakes of the Austrian Alps: potential effect of climatic warming on UV underwater attenuation. Arctic, Antarctic, and Alpine Research 31: 247-253.

Spaulding, S. A., M. K. Otu, A. P. Wolfe \& J. S. Baron, 2015. Paleolimnological records of nitrogen deposition in shallow, high-elevation lakes of Grand Teton National Park, Wyoming, U.S.A. Arctic, Antarctic, and Alpine Research 47: 703-717.

Stocker, T. F., 2020. Surprises for climate stability. Science 367(6485): 1425-1426.

Stoermer, E. F. \& J. P. Smol, 2010. Applications and use of diatoms: prologue. In Stoermer, E. F. \& J. P. Smol (eds), The Diatoms: Applications for the Environmental and EARTH SCIENCES. Cambridge University Press, Cambridge: $3-7$.

Teranes, J. L. \& S. M. Bernasconi, 2000. The record of nitrate utilization and productivity limitation provided by $\delta^{15} \mathrm{~N}$ values in lake organic matter - a study of sediment trap and core sediments from Baldeggersee, Switzerland. Limnology and Oceanography 45: 801-813.

Thompson, R., D. Price, N. Cameron, V. Jones, C. Bigler, P. Rosén, R. I. Hall, J. Catalan, J. García, J. Weckström \& A. Korhola, 2005. Quantitative calibration of remote 
mountain-lake sediments as climatic recorders of air temperature and ice-cover duration. Arctic, Antarctic and Alpine Research 37: 626-635.

Tõnno, I., K. Nauts, S. Belle, M. Nõmm, R. Freiberg, T. Kõiv \& T. Alliksaar, 2019. Holocene shifts in the primary producer community of large, shallow European Lake Peipsi, inferred from sediment pigment analysis. Journal of Paleolimnology 61: 403-417.

Thottathil, S. D., P. C. J. Reis, P. A. del Giorgio \& Y. T. Prairie, 2018. The extent and regulation of summer methane oxidation in northern lakes. Journal of Geophysical Research: Biogeosciences. 123: 3216-3230.

Valeton, I., 1988. Sedimentäre Phosphatgesteine. In Füchtbauer, N. (ed) Sedimente und Sedimentgesteine. E. Schweizbart, Stuttgart: 543-567.

Vinebrooke, R. D. \& P. R. Leavitt, 1998. Direct and interactive effects of allochthonous dissolved organic matter, inorganic nutrients, and ultraviolet radiation on an alpine littoral food web. Limnology and Oceanography 43: 1065-1081.

Vollenweider, R. A., 1968. Scientific Fundamentals of the Eutrophication of Lakes and Flowing Waters, with Particular Reference to Nitrogen and Phosphorus as Factors in Eutrophication. Report. Organization for Economic Cooperation and Development, Paris.

Warscher, M., S. Wagner, T. Marke, P. Laux, G. Smiatek, U. Strasser \& H. Kunstmann, 2019. A $5 \mathrm{~km}$ resolution regional climate simulation for Central Europe: performance in high mountain areas and seasonal, regional and elevation-dependent variations. Atmosphere 10: 682.

Weckström, J., A. Korhola \& T. Blom, 1997. The relationship between diatoms and water temperature in thirty Subarctic Fennoscandian lakes. Arctic and Alpine Research 29: 75-92.

Weckström, J., S. Hanhijärvi, L. Forsström, E. Kuusisto \& A. Korhola, 2014. Reconstructing lake ice cover in Subarctic lakes using a diatom-based inference model. Geophysical Research Letters 41: 2026-2032.
Weckström, K., J. Weckström, K. Huber, C. Kamenik, R. Schmidt, W. Salvenmoser, M. Rieradevall, T. Weisse, R. Psenner \& R. Kurmayer, 2016. Impacts of climate warming on alpine lake biota over the past decade. Arctic, Antarctic, and Alpine Research 48: 361-376.

Werner, P. \& J. P. Smol, 2006. The distribution of the diatom Cyclotella comensis in Ontario (Canada) lakes. Nova Hedwigia, Beiheft 130: 373-392.

Wetzel, R. G., 2001. Limnology Lake and River Ecosystems. Academic, San Diego.

Wilhelm, B., F. Arnaud, P. Sabatier, C. Crouzet, E. Brisset, E. Chaumillon, J.-R. Disnar, F. Guiter, E. Malet, J.-L. Reyss, K. Tachikawa, E. Bard \& J.-J. Delannoy, 2012. 1400 Years of extreme precipitation patterns over the Mediterranean French Alps and possible forcing mechanisms. Quaternary Research 78: 1-12.

Wilhelm, B., F. Arnaud, P. Sabatier, O. Magand, E. Chapron, T. Courp, K. Tachikawa, B. Fanget, E. Malet, C. Pignol, E. Bard \& J. J. Delannoy, 2013. Palaeoflood activity and climate change over the last 1400 years recorded by lake sediments in the north-west European Alps. Journal of Quaternary Science 28(2): 189-199.

Winder, M., J. E. Reuter \& S. G. Schladow, 2009. Lake warming favours small-sized planktonic diatom species. Proceedings of the Royal Society B: Biological Sciences 27: 427-435.

Winder, M. \& U. Sommer, 2012. Phytoplankton response to a changing climate. Hydrobiologia 698: 5-16.

Wright, S. W., S. W. Jeffrey, R. F. C. Mantoura, C. A. Llewellyn, T. Bjornland, D. Repeta \& N. Weelschmeyer, 1991. Improved HPLC methods for the analysis of chlorophylls and carotenoids from marine phytoplankton. Marine Ecologic Progress Series 77: 183-196.

Publisher's Note Springer Nature remains neutral with regard to jurisdictional claims in published maps and institutional affiliations. 